\title{
Protecting Privacy Under the Fourth Amendment
}

The Fourth Amendment ${ }^{1}$ has explicitly been held to protect personal privacy ${ }^{2}$ since at least the mid-nineteenth century. ${ }^{3}$ Experts in many fields, including law, psychology, philosophy and sociology, believe that privacy is vitally important to all human beings, ${ }^{4}$ and the Supreme Court has

\section{The Fourth Amendment provides that:}

The right of the people to be secure in their persons, houses, papers, and effects, against unreasonable searches and seizures, shall not be violated, and no Warrants shall issue, but upon probable cause, supported by Oath or affirmation, and particularly describing the place to be searched, and the persons or things to be seized.

U.S. CONST. amend. IV.

Under the Fourteenth Amendment, the states must comply with the provisions of the Fourth Amendment. Mapp v. Ohio, 367 U.S. 643, 655 (I961).

2. As a constitutional concept, privacy is an elusive yet fundamental value. Although the word "privacy" does not appear in the Constitution, the Supreme Court has recognized a constitutional right to privacy based upon provisions of the First, Third, Fourth, Fifth, and Ninth Amendments and their respective "penumbras." Griswold v. Connecticut, 381 U.S. 479, 484-85 (1965); cf. Beaney, The Constitutional Right to Privacy in the Supreme Court, 1962 SUP. CT. REV. 212, 215 ("The nearest thing to an explicit recognition of a right to privacy in the Constitution is contained in the Fourth Amendment".) This right to privacy is a "fundamental personal right, emanting "from the totality of the constitutional scheme." " Griswold v. Connecticut, 381 U.S. 479, 494 (1965) (Goldberg, J., concurring) (quoting Poe v. Ullman, 367 U.S. 497, 521 (1961) (Douglas, J., dissenting)); see notes 4-5 infra. While recognizing that privacy is constitutionally significant in many areas of law, see, e.g., Cantrell v. Forest City Publishing Co., 419 U.S. 245 (1974) (libel); Kewanee Oil Co. v. Bicron Corp., 416 U.S. 470 (1974) (trade secrets); Roe v. Wade, 410 U.S. 113 (1973) (abortion); Katz v. United States, 389 U.S. 347 (1967) (search and seizure), the Court has not offered any specific or comprehensive constitutional definition of privacy. See note 79 infra (discussing Supreme Court's attempts to define privacy). See generally Posner, The Uncertain Protection of Privacy by the Supreme Court, 1979 SUP. CT. REV. 173.

Some states have amended their constitutions in recent years to recognize expressly the right to privacy. See, e.g., ALASKA CONST. art. I, $\S 22$ ("The right of the people to privacy is recognized and shall not be infringed."); CAL. CONST. art. I, $\$ 1$ ("inalienable rights" include "pursuing and obtaining . . . privacy"); MONT. CONST. art. II, $\S 10$ ("The right of individual privacy is essential to the well-being of a free society and shall not be infringed without the showing of a compelling state interest.") Such state provisions, however, also fail to provide a specific definition of privacy.

3. See, e.g., Boyd v. United States, 116 U.S. 616, 630 (1886) (Fourth Amendment protects "the privacies of life"); Ex parte Jackson, 96 U.S. 727, 733 (1877) (Fourth Amendment protects "secrecy of letters and ... packages"); T. COOLEY, CONSTITUTIONAL LIMITATIONS 304 (1st ed. Boston 1868) (requirements of Fourth Amendment's warrant clause must be met before "privacy . . . is allowed to be invaded").

4. Privacy is said to be vital to the mental, spiritual, and physical well-being of all individuals. See 1. AltMinN, THE ENVIRONMENT AND SOCIAL BEHAVIOR: PRIVACY, PERSONAL SPACE, TERRITORY AND CROWDING 50 (1975) (privacy "vital to self-definition"); A. WESTIN, PRIVACY AND FREEDOM 39 (1967) (privacy "basically an instrument for achieving individual goals of self-realization"); Fried, Privacy, 77 Yale L.J. 475, 478 (1968) (privacy vital to "morality"); Gavison, Privacy and the Limits of the Law, 89 YALE L.J. 421, 447 (1980) (privacy "essential" for "learning, writing, and all forms of creativity," as well as for physical relaxation); Jourard, Some Psychological Aspects of Privacy, 31 LAW \& CONTEMP. PROBS. 307, 310 (1966) (privacy enables individuals to cope with public pressures and maintain "physical health and ... psychological and spiritual well-being"). Privacy is also essential for the successful pursuit and maintenance of interpersonal relationships. See Benn, Privacy, Freedom, and Respect for Persons, in NOMOS XIII 1, 17 (J.R. Pennock \& J. Chapman eds. 1971) (personal relations "could not exist" without privacy); Fried, supra, at 477 (relationships of love, 
often noted that the right to privacy is fundamental. ${ }^{5}$ In recent years, protection of privacy has come to be viewed as "the principal object of the Fourth Amendment." Since its 1967 decision in Katz v. United States, the Supreme Court has maintained that an individual is protected by the Fourth Amendment whenever he or she has a "reasonable expectation of privacy." Yet today the Court and scholars alike acknowledge that the constitutional law of search and seizure as it operates to protect privacy is in disarray. ${ }^{9}$ Some lower courts, extrapolating from undeveloped intimations from the Supreme Court, have suggested the existence of a new, undefined exception to the usual Fourth Amendment warrant requirement, one that refuses full Fourth Amendment protection to privacy interests perceived as lesser, trivial, or unimportant. ${ }^{10}$ Use of this "lesser expectation of privacy" analysis has led to disparate and conflicting judicial decision $\mathrm{s}^{11}$ and subtle manipulation of privacy protection under the Fourth Amendment.

This Note contends that reliance on a concept of reasonable expectations to define the scope of the Fourth Amendment's privacy protection confuses analysis and should be abandoned. Furthermore, the Note argues that a warrant requirement exception based on the perceived "lesser" status of certain privacy interests represents a significant departure from traditional Fourth Amendment principles, and is unworkable and unjusti-

friendship and trust "inconceivable" without privacy); Gavison, supra at 450 (privacy "crucial" to human relationships). Finally, privacy has been identified as a necessary element of any free and tolerant democratic state. See E. SHILS, THE TORMENT OF SECRECY 22-24 (1956) (privacy vital to "liberal democracy"); Simmel, Privacy is Not an Isolated Freedom, in NOMOS XIII, supra, at 79, 8687 (privacy necessary for "freedom" and "open society"). See generally A. WESTIN, supra note 42, at 23-51 ("Privacy in the Modern Democratic State").

5. See, e.g., Kewanee Oil Co. v. Bicron Corp., 416 U.S. 470, 487 (1974) (privacy is "[a] most fundamental human right"); Roe v. Wade, 410 U.S. 113, 152 (1973) (same); Stanley v. Georgia, 394 U.S. 557, 564 (1969) (same); cf. Privacy Act of 1974, Pub. L. No. 93-579, § 2(a), 88 Stat. 1896, 1896 (currently codified at 5 U.S.C. $\$ 552(a)(1976)$ ) ("Congress finds that . . . the right to privacy is a personal and fundamental right protected by the Constitution of the United States".)

6. Warden v. Hayden, 387 U.S. 294, 304 (1967); accord Wolf v. Colorado, 338 U.S. 25, 27 (1949) ("The security of one's privacy against arbitrary intrusion by the police . . . is at the core of the Fourth Amendment .....")

7. 389 U.S. 347 (1967).

8. See pp. $315-16$ infra (discussing reasonable expectation of privacy test).

9. See, e.g., Robbins v. California, 101 S. Ct. 2841, 2848 (1981) (Powell, J., concurring) ("[T]he law of search and seizure . . is intolerably confusing. The Court apparently cannot agree even on what it has held previously, let alone on how [the instant] cases should be decided."); Williamson, Fourth Amendment Standing and Expectations of Privacy: Rakas v. Illinois and New Directions for Some Old Concepts, 31 U. FLA. L. REV. 831, 837 (1979) (Supreme Court "has neglected to delineate a workable substantive definition of the scope of fourth amendment protections"); Survey, The Fourth Amendment and the Sixth Circuit: A Survey of Search and Seizure Decisions, 12 TOL. L. REv. 511, 547 (1981) (current Fourth Amendment jurisprudence is "ad hoc and inconsistent body of case law distinguished only by its essential lawlessness").

10. See pp. 322-26 infra (discussing development of lesser expectation of privacy exception).

11. See notes 104-105 infra (listing cases in which lower courts have reached opposite conclusions when applying lesser expectation of privacy analysis to container searches). 
fiable. After suggesting "secrecy and solitude" as the starting point for an inclusive yet objective and sociologically accurate definition of privacy, the Note proposes that any government action that violates an individual's privacy interests should be subjected to full Fourth Amendment protection based on well-developed principles of Fourth Amendment jurisprudence. Applying the suggested analysis to container searches, the Note demonstrates that a "closed, opaque container" rule is appropriate, and recommends reappraisal of recent holdings that have been reached under the expectation of privacy approach.

\section{The Fourth Amendment and Privacy}

Fourth Amendment analysis has traditionally involved two determinations: first, whether a claim falls within the Amendment's scope, ${ }^{12}$ and second, whether the government has complied with the Amendment's protective requirements. ${ }^{13}$ Over time, the Supreme Court has developed a strict warrant requirement as the primary means of ensuring that the Amendment's protective commands are complied with by executive officers. Yet today some courts are acting to forego the warrant requirement in cases in which they determine that only "lesser" privacy interests within the scope of the Fourth Amendment have been violated.

\section{A. The Reasonable Expectation of Privacy Test}

Although the Fourth Amendment by its terms protects property ${ }^{14}$ it has long been recognized that the Amendment functions to protect privacy as well. ${ }^{15}$ In the landmark decision of Katz v. United States, ${ }^{16}$ the Supreme Court held that privacy interests could be protected under the Fourth Amendment even when no property rights were infringed. ${ }^{17}$ Specifically,

12. Only actions that constitute "searches" or "seizures" are restricted by the Fourth Amendment. United States v. Dionisio, 410 U.S. 1, 9, 15 (1973) (by implication); Terry v. Ohio, 392 U.S. 1, 16 (1968).

13. The Fourth Amendment governs the conduct only of government agents and not that of private parties. Burdeau v. McDowell, 256 U.S. 465, 475 (1921).

The only explicit requirement of the Fourth Amendment is that searches and seizures must not be "unreasonable." The Supreme Court has held, however, that two further nontextual Fourth Amendment requirements must be met for most searches and seizures: probable cause, see Carroll v. United States, 267 U.S. 132, 149 (1925) (noting "true rule" that searches and seizures "made upon probable cause . . . are valid"); accord, Ybarra v. Illinois, 444 U.S. 85, 90-91 (1979); see note 30 infra (defining probable cause); and use of prior warrants, see pp. 316-18 infra (describing development and components of warrant requirement).

14. The Amendment guarantees the security of "persons, houses, papers, and effects." U.S. CONST, amend. IV.

15. See note 3 supra (citing authorities); pp. 319-21 infra (discussing protective value of warrants for privacy).

16. 389 U.S. 347 (1967).

17. Id. at 352-53. This decision to abandon a purely property-based analysis of Fourth Amendment claims had been foreshadowed in Warden v. Hayden, 387 U.S. 294, 304 (1967) ("The premise 
the Court ruled that Katz had an interest in the confidentiality of his telephone conversations that was protected against warrantless wiretapping, even though his calls were made from a public phone booth. ${ }^{18}$ By protecting this privacy interest, the Court enlarged the Fourth Amendment's protective scope to encompass governmental intrusions in any private context. ${ }^{19}$

Concurring in Katz, Justice Harlan advanced the now-familiar twopart "reasonable expectation of privacy" test as a means of identifying protected Fourth Amendment claims: first, the expectation must be an "actual" one, subjectively held by the person affected by the search; second, the expectation must be "one that society is prepared to recognize as 'reasonable." " ${ }^{20}$ Despite its origin in a concurring opinion, this reasonable expectation of privacy formula has emerged as the judicial "lodestar" for current Fourth Amendment analysis. ${ }^{21}$

\section{B. The Warrant Requirement and Protection of Privacy}

In the wake of this relatively recent shift to a focus on privacy, some courts have suggested that a strict requirement of prior warrants is unnecessary in Fourth Amendment analysis when the privacy interests at stake are perceived to be small or unimportant. ${ }^{22}$ In order to adequately evalu-

that property interests control the right of the Government to search and seize has been discredited."), and in Silverman v. United States, 365 U.S. 505, 511 (1961) ("Fourth Amendment rights are not inevitably measurable in terms of ancient niceties of . . . real property law.") The proper relationship between property and privacy claims in Fourth Amendment analysis remains unclear, however. Compare Rakas v. Illinois, 439 U.S. 128 (1978) (standing denied because no property interest shown) with Rawlings v. Kentucky 448 U.S. 98 (1980) (standing denied despite showing of property interest). See generally Note, Property Law and Fourth Amendment Privacy Protection, 58 NEB. L. REv. 1123 (1979).

18. 389 U.S. at 351-52.

19. By holding that the Fourth Amendment "protects people, not places," 389 U.S. at 351, the Court in Katz expressly rejected suggestions in earlier decisions that the Amendment's protections attached only in certain "constitutionally protected areas," see, e.g., Berger v. New York, 388 U.S. 41, 57, 59 (1967); Goldman v. United States, 316 U.S. 129, 134-36 (1942).

20. 389 U.S. at 361.

21. Smith v. Maryland, 442 U.S. 735,739 (1979). Soon after the phrase was suggested by Justice Harlan in his concurrence to Katz, 389 U.S. at 361 , a majority of the Court adopted the reasonable expectation of privacy test in Terry v. Ohio, 302 U.S. 1, 9 (1968) ("WWherever an individual may harbor a reasonable 'expectation of privacy,' he is entitled to be free from unreasonable government intrusion.") (citation omitted). The Court has subsequently used "legitimate" or "justifiable" in place of reasonable, but apparently intends all three terms to be synonymous in the expectation of privacy context. See Smith v. Maryland, 442 U.S. 735, 740 (1979) (protection under Fourth Amendment "depends on whether the person invoking its protection can claim a 'justifiable,' a 'reasonable,' or a 'legitimate expectation of privacy" ").

Despite its current "lodestar" status, the reasonable expectation of privacy test has been the object of strong and continuing academic criticism. See, e.g., Amsterdam, Perspectives on the Fourth Amendment, 58 MinN. L. REV. 349, 383-86 (1974); Walinski \& Tucker, Expectations of Privacy: Fourth Amendment Legitimacy Through State Law, 16 HARV. C.R.-C.L. L. REV. 1, 2-4 (1981); Note, A Reconsideration of the Katz Expectation of Privacy Test, 76 MICH. L. REV. 154, 157-70 (1977).

22. See pp. 322-26 infra (discussing emergence of lesser expectation of privacy exception to warrant requirement). 
ate this development, it is helpful to review the warrant process and the protections it provides for privacy.

The warrant process has long been a familiar component of Fourth Amendment analysis. ${ }^{23}$ Although the precise function of warrants is not self-evident from the text of the Amendment, the Supreme Court has concluded that to comply with the spirit of the Amendment, law enforcement officers must generally obtain a warrant from a neutral judicial officer before conducting any search or seizure. ${ }^{24}$ Under this doctrine, warrantless searches and seizures are "per se unreasonable,"25 and the warrant requirement will be waived only under a few "carefully and jealously drawn" exceptions-circumstances in which compliance with the warrant process would exact some heavy social cost. ${ }^{26}$

23. The Framers were familiar with the concept of obtaining prior authorization to search and seize, because warrants were used in Great Britain and America long before the Fourth Amendment was written. By the late seventeenth century, the Lord Chief Justice of the King's Bench, Sir Matthew Hale, had already written a treatise recommending a judicially-supervised warrant system embodying requirements of probable cause and particularity. See M. HALE, THE HISTORY OF THE PLEAS OF THE GROWN 110-14, 149r-51 (1st Am. ed. Philadelphia 1847) (1st ed. London 1736). The warrant clause of the Fourth Amendment, therefore, did not embody a completely new concept, and its specifics were designed to prohibit the use of hated "general" warrants or writs of assistance, which had been issuable by agents of the King or legislature and had given officers blanket authority to search without cause. See generally N. LASSON, THE HISTORY AND DEVELOPMENT OF THE FOURTH AMENDMENT TO THE UNITED STATES CONSTITUTION, reprinted in 55 JOHNS HOPKINS U. STUD. HIST. \& POL. SCI., No. 2, at 34-105 (1937); T. TAYLOR, TWO STUDIES IN CONSTITUTIONAL INTERPRETATION 24-41 (1969). Early Fourth Amendment cases referred to the warrant process and its requirements with familiarity, see, e.g., Ex parte Jackson, 96 U.S. 727, 733 (1877); Ex parte Burford, 7 U.S. (3 Cranch) 448, 451 (1806).

24. The Fourth Amendment does not specify how its commands are to be followed or enforced, and its text has been criticized as "brief, vague, general, [and] unilluminating." Amsterdam, supra note 21, at 353-354. Accord, Coolidge v. New Hampshire, 403 U.S. 443, 484 (1971) (noting "uncertain mandate" of Fourth Amendment); Weinreb, Generalities of the Fourth Amendment, 42 U. CHI. L. REV. 47, 47 (1974) (Fourth Amendment is "one of the Constitution's richly generative texts . . . . [and] does not answer specific questions"). The initial clause of the Amendment forbids "unreasonable" searches and seizures, while the second clause prescribes certain requirements for valid warrants without indicating when or whether warrants are required. Consequently, the proper relationship between the two clauses has been vigorously contested. Compare T. TAYLOR, supra note 23, at 41 (Fourth Amendment should not be read to require warrants, because Framers intended only to restrict use of "overreaching warrants" and "were not concerned about warrantless searches") with Amsterdam, supra note 21, at 414 (warrant requirement is correct result of "sound constitutional logic") and Stelzner, The Fourth Amendment: The Reasonableness and Warrant Clauses, 10 NEW MEX. L. REV. 33, 40 (1979-80) (historical evidence indicates that First Congress intended that Fourth Amendment would require warrants). Since its decision thirteen years ago in Chimel v. California, 395 U.S. 752, 762 (1969) (finding "general requirement that a search warrant be obtained"), however, the Supreme Court has steadfastly held that a valid warrant must be obtained before a search or seizure is conducted, unless substantial justifications are presented for foregoing the warrant process. See, e.g., New York v. Belton, $101 \mathrm{~S}$. Ct. 2860, 2862 (1981) (warrant requirement is "a first principle of Fourth Amendment jurisprudence"); Arkansas v. Sanders, 442 U.S. 753, 759 (1979) (noting "prominent place the warrant requirement is given" in Supreme Court's Fourth Amendment decisions).

25. Katz v. United States, 389 U.S. 347, 357 (1967); accord Mincey v. Arizona, 437 U.S. 385, 390 (1978); Coolidge v. New Hampshire, 403 U.S. 443, 481 (1971).

26. Jones v. United States, 357 U.S. 493, 499 (1959); accord Arkansas v. Sanders, 442 U.S. 753, 759-60 (1979); United States v. United States District Court, 407 U.S. 297, 318, 320-21 (1972). See pp. 321-22 infra (discussing exceptions to warrant requirement). 
The basic warrant procedure is uncomplicated. ${ }^{27}$ To obtain a valid warrant, a law enforcement officer must demonstrate to a judicial officer ${ }^{28}$ through sworn affadavits ${ }^{29}$ that probable cause ${ }^{30}$ exists to believe that criminal contraband or evidence will be found at a particular location. ${ }^{31}$ If factors of time or distance make the requirement of in-person written affidavits impracticable, oral testimony may be substituted via telephone or other communicative device. ${ }^{32}$ Because officers are permitted to act immediately without a warrant whenever delay might result in harm to others

27. Rule 41 of the Federal Rules of Criminal Procedure governs the issuance and execution of federal search and seizure warrants. Most states have enacted similar rules. See, e.g., CAL. PEN. CODE $\S \S 1523-1542$ (West 1970 \& Supp. 1981); N.Y. CRIM. PROC. L $\Lambda W ~ \$ \$ 690.05-690.55$ (McKinney 1971 \& Supp. 1975); ILL. ANN. STAT., ch. $38, \S \S 108-3$ through 108-14 (Smith-Hurd 1980 \& Supp. 1981).

28. Either a federal magistrate or a "judge of a state court of record" may issue a federal search warrant upon sworn affidavits. FED. R. CRIM. P. 41(a). Only federal magistrates, however, may authorize warrants upon oral testimony. FED. R. CRIM. P. 41(c)(2)(A). In no case may search warrants be issued by persons other than "neutral judicial officers." See p. 319 infra (discussing requirement of neutral judicial officers).

29. The Fourth Amendment requires that warrants be "supported by Oath or affirmation," U.S. CONST. amend. IV, to ensure that "someone . . . take the responsibility for the facts alleged." United States ex rel. Pugh v. Pate, 401 F.2d 6, 7 (7th Cir. 1968), cert. denied, 394 U.S. 999 (1969); see also Frazier v. Roberts, 441 F.2d 1224, 1228 (8th Cir. 1971) (per curiam) (unsworn assertions "for which the informing officer takes no moral or legal responsibility" are insufficient to support warrant).

30. "[P]robable cause is a practical, nontechnical conception," Brinegar v. United States, 338 U.S. 160,176 (1949), and facts constituting probable cause will differ from case to case. The best general definition is still that which may be gleaned from Carroll v. United States, 267 U.S. 132, 149, 162 (1925):

[Probable cause is] a belief, reasonably arising out of circumstances known to the seizing of-

ficer, that [the area to be searched] contains that which by law is subject to seizure . . . This is to say ... where the facts and circumstances within their [the officers'] knowledge . . . were sufficient in themselves to warrant a man of reasonable caution in the belief that [contraband or evidence would be found in the area searched].

Probable cause requires "less than evidence which would justify condemnation' or conviction," but "more than bare suspicion." Brinegar v. United States, 338 U.S. 160, 175 (1949) (quoting Locke v. United States, 11 U.S. (7 Cranch) 339, 348 (1813)).

31. The Fourth Amendment requires that warrants "particularly describ[e] the place to be searched, and the persons or things to be seized." U.S. CONST. amend. IV. See p. 320 infra (discussing particularity requirement).

32. FED. R. CRIM. P. 41(c)(2). Similar provisions have been enacted by some states, see, e.g., ARIZ. REV. STAT. ANN. § 13-3914(c) (West 1978 \& Supp. 1981); CNL. PEN. CODE $\$ \S 1526(b)$, 1528(b) (West Supp. 1981). Such "telephonic warrants" significantly reduce the time required to obtain a warrant. See Miller, Telephonic Search Warrants: The San Diego Experience, 9 PRosECU. TOR 385, 385-86 (1973) ("search warrants [are] issued in minutes rather than hours" via oral warrant system). According to the former San Diego District Attorney, "65\% of all telephonic search warrants take one hour or less [to obtain] ... . Most of the remaining 35\% are completed in less than 2 hours," and longer delay is frequently attributable to factors extraneous to the warrant procedure. Id. Accord, Note, Oral Search Warrants: A New Standard of Warrant Availability, 21 U.C.L.A. L. REV. 691, 694 n.23 (1973) (citing cases where telephonic warrants were obtained in 12 and 34 minutes). Because oral testimony reduces demeanor evidence available to the magistrate and may also make the probable cause determination more difficult in complex cases, however, telephonic warrants may be used only in situations where time or distance would make use of the conventional procedure unreasonable. See generally FED. R. CRIM. P. 41(c)(2)(A) (Advisory Committee Notes to 1977 Amendment); Israel, Legislative Regulation of Searches and Seizures: The Michigan Proposals, 73 MicH. L. REV. 221, 258-63 (1974). 
or loss or destruction of evidence, ${ }^{33}$ the only cost of the warrant process in theory is the administrative expense of compliance to law enforcement agencies. ${ }^{34}$

The primary value of the warrant requirement lies in its function as a judicial limitation on executive discretion, in the constitutional tradition of separation of powers. ${ }^{35}$ Only a neutral judicial officer, detached from "the often competitive enterprise of ferreting out crime," is permitted to issue a warrant. ${ }^{36}$ The presumption is that a magistrate will refuse the warrant for unreasonable searches that overzealous officers might otherwise have conducted. ${ }^{37}$

33. See p. 322 \& note 49 infra (discussing "exigent circumstances" exception to warrant requirement).

34. The Supreme Court has stated that the "burden imposed on the police by a warrant requirement is minimal." Steagald v. United States, 451 U.S. 204, 222 (1981). No empirical research has been done concerning the costs involved, see note 110 infra, however, and reported cases reveal that the time required to obtain a search warrant upon written affidavit can vary widely. Compare Barajas v. Superior Court, 10 Cal. App. 3d 185, 188, 88 Cal. Rptr. 730, 731 (1970) (less than 2.5 hours) with United States v. Van Leeuwen, 397 U.S. 249, 250253 (1970) (between 7 and 29 hours). The amount of delay, however, is usually stated in terms of hours, rather than days or some longer measure. See Griswold, Criminal Procedurc, 1969-Is It a Means or an End? 29 MD. L. REV. 317 (1969); Note, supra note 32 , at 693 n.18.

Nevertheless, the "most frequent police objection to the use of search warrants is that the application process is too time-consuming." Israel, supra note 32 , at 256 . Besides delays in the normal process itself, long distances between law enforcers and magistrates in rural areas, or unavailability of magistrates, may lengthen the application period. See Robbins v. California, 101 S. Ct. 2841, 2852 (1981) (Rehnquist, J., dissenting) (scarcity of magistrates in southwestern "cow counties" makes warrant requirement burdensome); FED. R. CRIM. P. 41 (Advisory Committee Notes to 1977 Amendment) (noting "administrative difficulties involved in getting a warrant, particularly at times of the day when a judicial officer is ordinarily unavailable").

Since 1977 , however, the availability of telephonic warrants has significantly reduced the time burdens involved in secking warrants, see note 32 supra; cf. Miller, supra note 32, at 385-86 (telephone warrant system "operates in a quick and simple manner," and "greatly expanded the total number of search warrants issued" in San Diego). Thus, the Supreme Court has judicially noted the availability of telephonic warrants when stating that "the short time required to obtain a search warrant . . . will seldom hinder [law enforcement] efforts." Steagald v. United States, 451 U.S. 204, 222 (I981).

35. See United States v. United States Dist. Court, 407 U.S. 297, 317 (1972) ("judicial role" in warrant process accords with "our basic constitutional doctrine" of "separation of powers").

36. Johnson v. United States, 333 U.S. 10, 14 (1948); accord, United States v. United States Dist. Court, 407 U.S. 297, 316 (1972) ("Inherent in the concept of a warrant is its issuance by a "neutral and detached magistrate." "); cf. Coolidge v. New Hampshire, 403 U.S. 443, 453 (1971) (warrant invalid because issued by state Attorney General who was "chief investigator and prosecutor" in case).

37. Cr. United States v. United States Dist. Court, 407 U.S. 297, 317 (1972) ("The historical judgement . . . is that unreviewed executive discretion may yield too readily to pressures to obtain incriminating evidence and overlook potential invasions of privacy.") This presumption has been questioned on the ground that many persons who are empowered to issue warrants actually exercise little discretion and issue warrants as a matter of course. See, e.g., Robbins v. California, 101 S. Ct. 2841, 2852 (1981) (Rehnquist, J., dissenting) (criticizing warrant requirement in light of previous Supreme Court decision that permits city clerks who are "not trained in the law" to issue warrants); Miller \& Tiffany, Prosecutor Dominance of the Warrant Decision: A Study of Current Practices, 1964 WASH. U.L.Q. 1 (empirical evidence suggests that magistrates perform little screening). Such criticism, however, does not disprove the validity of the theory, but rather indicates only that its implementation ought to be improved. See Note, supra note 32, at 691-92 n.4 (response to inadequacies of magistrate review should not be to discontinue review of police actions, but rather to develop "clear standards of review" to guide magistrates); cf. Yackle, The Burger Court and the Fourth Amendment, 26 U. KAN. L. REV. 335, 415 (1978) (if Supreme Court strictly enforced a clear warrant 
The particularity requirement of the warrant clause further limits executive discretion by placing specific boundaries on the scope of an intrusive action. ${ }^{38}$ By limiting the objects and parameters of a search, this aspect of the warrant requirement prevents indiscriminate "general" searches of the character that most motivated the Framers to include the Fourth Amendment in the Bill of Rights. ${ }^{39}$

The value of the warrant requirement in protecting privacy is clearest when the process is compared to its likely alternative: after-the-fact judicial review of a search or seizure for "reasonableness." ognize that privacy, once disturbed, cannot be restored in the same way that wrongfully-seized property can be returned if a post-search reviewer finds that "the constable blundered." 41 A prior determination of the reasonableness of and probable cause for a search is therefore of critical importance in protecting privacy. Furthermore, prior review avoids the "fa-

requirement, "judicial supervision might yet become effective despite the shortcomings of the past").

38. "A search for a stolen horse, for example, could not include the shredding of a bedroom mattress." Greenawalt, The Right of Privacy, in THE RIGHTS OF AMERICANS 299, 306 (N. Dorsen ed. 1970). See, e.g., Lo-Ji Sales, Inc. v. New York, 442 U.S. 319, 325 (1979) (striking down "open ended" warrant whose terms left scope of search "entirely to the discretion of the officials conducting the search"); Berger v. New York, 388 U.S. 41, 58-60 (1967) (striking down "permissive eavesdropping" statute because it "authorize[d] the 'indiscriminate use' of electronic devices" and gave officials "roving commission" to eavesdrop).

39. See United States v. Chadwick, 433 U.S. 1, 7-8 (1977) ("It cannot be doubted that the Fourth Amendment's commands grew in large measure out of the colonists' experience with writs of assistance and their memories of the general warrants formerly in use in England."); see generally $\mathrm{N}$. LASSON, supra note 23, at 57-81 (discussing writs of assistance and general warrants).

40. Courts may review police actions either in a criminal setting-for example, a suppression hearing or trial-or in a civil action brought by the victim of a suit against the searching officer or officers. See Bivens v. Six Unknown Named Agents, 403 U.S. 388 (1971) (Fourth Amendment creates cause of action for damages if violated). Knowledge that their actions may be subject to such postsearch review may encourage law enforcement officers to act reasonably, and thus provide some measure of protection for privacy interests. Such foreknowledge will provide no privacy protection against intrusive actions taken in good faith, however. Cf. Chimel v. California, 395 U.S. 752, 766 n.12 (1969) ("The [Fourth] Amendment is designed to prevent, not simply to redress, unlawful police action.") Furthermore, civil actions against offending officers are unlikely to provide much relief, because good faith is a defense to such actions and courts pay great deference to law enforcement officers. See Steagald v. United States, 451 U.S. 204, 216 n.9 (1981) (noting "pitfalls and limitations" of Fourth Amendment civil actions); Bivens v. Six Unknown Named Agents, 456 F.2d 1339, 1347 (2d Cir. 1972) (on remand from Supreme Court) (granting good faith defense to federal officers in Fourth Amendment civil action because officers, "whose lives are in constant danger . . . , perform functions indispensable to the preservation of our American way of life"). In a criminal setting, the remedy for Fourth Amendment violation is exclusion of illegally seized evidence along with its fruits from use at trial. See Mapp v. Ohio, 367 U.S. 643 (1961); Weeks v. United States, 232 U.S. 383 (1914). Again, good faith may be a bar to this remedy, see Williams v. United States, 622 F.2d 830 (5th Cir. 1980) (en banc) (per curiam), cert. denied, 449 U.S. 1127 (1981) (refusing to apply exclusionary rule when officers acted in good faith).

41. People v. Defore, 242 N.Y. 13, 21, 150 N.E. 585, 587, 214 N.Y.S. (Cardozo, J.), cert. denied, 270 U.S. 657 (1926). As a psychological state, privacy may be damaged irreparably by an unwarranted intrusion; an individual may return to a state of privacy after a disruption, but lost privacy cannot be restored. See note 43 infra (discussing psychological implications of privacy invasion). Because property is concrete, it is substantially unaffected by a temporary seizure, and the only irremedial effect is loss of its use during the seizure period. 
miliar shortcomings of hindsight judgement" that may, in close cases, lead courts acting after the fact to rule against apparently guilty defendants. ${ }^{42}$

The warrant procedure is socially valuable even in cases in which an intrusion on privacy is ultimately permitted. A search by itself is psychologically intrusive, whether or not anything incriminating is actually discovered. ${ }^{43}$ By providing notice and assurance to the victim that an impending search has been judicially authorized and delimited, a valid warrant reduces anxiety and the perceived intrusiveness of the action. ${ }^{44} \mathrm{~A}$ postsearch review cannot possibly serve this function. ${ }^{45}$

\section{The "Lesser Expectation of Privacy" Approach}

Despite the protections that a warrant affords, exceptions to the warrant requirement have occasionally been established in order to accomodate other compelling societal needs. ${ }^{46}$ Because such exceptions unavoid-

42. Beck v. Ohio, 379 U.S. 89, 96 (1964); accord, Katz v. United States, 389 U.S. 347, 358 (1967); see United States v. Martinez-Fuerte, 428 U.S. 543, 565 (1976) (one pupose of warrant requirement is "to prevent hindsight from coloring the evaluation of the reasonableness of a search or seizure"); cf. Note, Tracking Katz: Beepers, Privacy, and the Fourth Amendment, 86 YALE L.J. 1461,1476 (1977) ("it is both easy and psychologically appealing" to uphold warrantless searches in post-search reviews because "[o]nly the guilty appear to be affected").

43. One important component of personal privacy has been described as "interaction management"- that is, control over the circumstances under which an intrusion upon one's privacy occurs. Laufer \& Wolfe, Privacy as a Concept and a Social Issue: A Multidimensional Developmental Theory, $33 \mathrm{~J}$. SOC. ISsUES, No. 3, at 22, 33-35 (1977) (coining term). To be psychologically complete, therefore, privacy requires choice or control over when, where, how and with whom an individual will interact. Id. at 37-39; accord, A. WESTIN, supra note 4, at 39-42 (for mental stability and personal development, individuals need to control their environments to avoid having "too much" or "too little" privacy); Shils, Privacy: Its Constitution and Vicissitudes, 31 LAW \& CONTEMP. PROBS. 281, 282-83 (1966) ("voluntary consent" concerning intrusions is "essential component" of privacy). The victim of a police search has no control over the timing, methods, or scope of the search. This absence of control causes anxiety, even if the victim has nothing incriminating to hide. Furthermore, because privacy is necessary to the development of personal autonomy, sense of self-worth, and interpersonal relationships, see note 4 supra, an involutary disruption of privacy by police may be damaging in other ways.

44. See, e.g., Marshall v. Barlow's, Inc., 436 U.S. 307, 323 (1978) (providing "assurances from a neutral officer" that search is reasonable and judicially authorized, and notice to owner of "scope and objects of the search . . . are important functions for a warrant to perform"); Camara v. Municipal Court, 387 U.S. 523, 532-33 (1967) (warrant protects householders by informing them that administrative search is required and limited by law, and has been authorized by judicial officer); $c f$. United States v. United States Dist. Court, 407 U.S. 297, 321 (1972) (one value served by warrant requirement in context of domestic national security cases is "reassurance of the public generally that indiscriminate wiretapping and bugging of law-abiding citizens cannot occur").

45. In addition to providing added protection for privacy, the warrant process avoids excessive resort to the exclusionary penalty of Mapp. v. Ohio, 367 U.S. 643 (1967) (illegally seized evidence is inadmissible in subsequent criminal prosecution), by ensuring that officers do not search or seize unreasonably or without probable cause.

46. See Arkansas v. Sanders, 442 U.S. 753, 760 (1979) ("[W]e have limited the reach of each exception to that which is necessary to accomodate the identified needs of society.") Established exceptions to the warrant requirement may be roughly divided among three general categories: "consent," "administrative searches" and "exigent circumstances." Cf. Amsterdam, supra note 21, at 358-60 (separating exceptions into categories of "consent," "limited . . . routine searches," and "circumstances of haste").

Consent to a search eliminates the need for a warrant, and may be proffered by the party affected 
ably entail a reduced degree of protection for the privacy interests at stake, however, their bounds are "strictly circumscribed,"47 and "the burden is on those seeking the exemption to show the need for it." "In criminal law, the most common and important exception arises in "exigent" circumstances, situations where contraband or evidence might be lost or destroyed, or persons might be harmed, if officers were to delay in order to seek a warrant. ${ }^{49}$ The Supreme Court has refused to create exceptions when a demonstrated need is judged less compelling, however, ${ }^{50}$ and has never held that the administrative cost of warrants alone is reason enough to forego their use. ${ }^{51}$

Yet the Supreme Court has recently implied that certain expectations of privacy will not be protected by the warrant requirement, even when the traditional exceptions are inapplicable. In a line of decisions beginning with Chambers v. Maroney, ${ }^{52}$ the Court has upheld warrantless searches

or a third party with some measure of authority over the area searched. See United States v. Matlock, 415 U.S. 164, 171 \& n.7 (1974) (wife's consent to search common bedroom); Schneckloth v. Bustamonte, 412 U.S. 218 (1973) (personal consent).

Administrative searches are those conducted to achieve a valid public purpose in a noncriminal context according to a previously established routine procedure. See, e.g., United States v. MartinezFuerte, 428 U.S. 543, 556, (1976) (routine warrantless motor vehicle stops at fixed checkpoints justified by the "substantiality of the public interest" in checking "flow of illegal aliens"); South Dakota v. Opperman, 428 U.S. 364, 369 (1976) (routine inventory searches of impounded vehicles justified "in response to three distinct needs": protection of police from danger and from false claims of theft, and protection of property left in such vehicles); United States v. Biswell, 406 U.S. 311, 315 (1972) (warrantless inspections of gun shops justified as a "crucial part" of "federal efforts to prevent violent crime"). Routine procedures and a noncriminal context are not sufficient justification for an administrative search exception, however; it must also be demonstrated that enforcement of the warrant requirement would frustrate the claimed public purpose or be inappropriate in the context at issue. The Court has thus denied warrant requirement exceptions in some administrative contexts. See, e.g., Marshall v. Barlow's, Inc., 436 U.S. 307 (1978) (OSHA inspections); See v. City of Seattle, 387 U.S. 541 (1967) (fire code inspections of commercial buildings); Camara v. Municipal Court, 387 U.S. 523 (1967) (housing code inspections).

Exceptions based on exigent circumstances are discussed in note 49 infra.

47. Terry v. Ohio, 392 U.S. 1, 26 (1968); accord, Arkansas v. Sanders, 442 U.S. 753, 760 (1979).

48. United States v. Jeffers, 342 U.S. 48, 51 (1951); accord, Mincey v. Arizona, 437 U.S. 385, 390-91 (1978).

49. See Chimel v. California, 395 U.S. 752,763 (1969) (in conjunction with arrest, police may search "area from within which [arrestee] might gain possession of a weapon or destructible evidence"). Exceptions based upon exigent circumstances include "hot pursuit," see Warden v. Hayden, 387 U.S. 294, 298 (1967) (warrantless entrance and search of residence after police were informed that armed robber had entered five minutes earlier), "stop and frisk," see Terry v. Ohio, 392 U.S. 1, 27 (1968) (frisk of suspicious individual on street for weapons), incident to arrest (see Chimel supra); and the original "automobile exception," see Carroll v. United States, 267 U.S. 132 (1925) (stop and search of vehicle in transit based on probable cause where failure to stop and search would result in loss of contraband); see note 53 infra (discussing Carroll).

50. See, e.g., Mincey v. Arizona, 437 U.S. 385, 393 (1978) (refusing general exception for search of homicide scenes, sought on basis of the "public interest in the prompt investigation" of homicides); United States v. United States Dist. Court, 407 U.S. 297, 318-21 (1972) (refusing general exception for electronic surveillance of domestic organizations, sought on basis of governmental interest in preserving national security).

51. See p. $331 \&$ note 90 infra (citing Supreme Court cases).

52. 399 U.S. $42(1970)$. 
of automobiles that took place in the absence of any exigency. ${ }^{53}$ After experimenting with a series of unsatisfactory explanations for this result, ${ }^{54}$ the Court in 1974 announced a novel justification: such non-exigent searches are permissible because people hold a "lesser expectation of privacy" in their automobiles than in their homes. ${ }^{55}$ Despite the unsecure underpinnings of this rationale ${ }^{56}$ and the substantial academic criticism that this new "automobile exception" has received, ${ }^{57}$ the Court has contin-

53. Warrantless automobile searches first received constitutional scrutiny in Carroll v. United States, 267 U.S. 132 (1925). There the Supreme Court, taking judicial notice of the difficulties of Prohibition enforcement, the mobility of automobiles, and their common use in transporting contraband liquor, held that government agents without a warrant could stop and search a vehicle on the highway if they had probable cause to believe that the automobile contained contraband. Id. at 153, 155. This holding was consistent with the rule that exigent circumstances justify a warrantless search, see p. 322 supra, because the automobile was not otherwise subject to police seizure and could have been quickly driven out of the jurisdiction, thereby causing a loss of suspected contraband. Through inexact analysis over the years, however, this holding has been transformed into a generic exception to the warrant requirement for automobiles, regardless of exigency. Cr. Cady v. Dombrowski, 413 U.S. $433,442-443$ (1973) ("[W]arrantless searches of vehicles have been sustained in cases in which the possibility of the vehicle's being removed or evidence in it destroyed were remote, if not non-existent."). For thorough coverage of this legal doctrine, see generally Robb, The Carroll Case: The Expansion of the Automobile Exception in Warrantless Search and Seizure Cases, 15 WILLAMETTE L. REV. 39 (1978); Moylan, The Automobile Exception: What It Is and What It Is Not-A Rationale in Search of a Clearer Label, 27 MERCER L. REV. 987 (1976).

54. See, e.g., Cady v. Dombrowski, 413 U.S. 433, 439-41 (1973) (asserting "constitutional difference between houses and cars" based on "extensive regulation" of, and "frequency" of police contact with, automobiles); Almeida-Sanchez v. United States, 413 U.S. 266, 279 (1973) (Powell, J. concurring) (suggesting without citation or explanation that warrantless "search of an automobile is far less intrusive . . . than the search of one's person or of a building"); Chambers v. Maroney, 399 U.S. 42, 51-52 (1970) (mobility of impounded automobile somehow "still obtain[s] at the stationhouse," and that it is "debatable" whether "lesser intrusion" would be continuing impoundment until warrant was obtained, or immediate warrantless search).

55. Cardwell v. Lewis, 417 U.S. 583, 590 (1974) ("One has a lesser expectation of privacy in a motor vehicle becuase its function is transportation and it seldom serves as one's residence or as the repository of personal effects.")

56. Cardwell was only a plurality opinion, and Justice Blackmun's reference to the alleged "lesser expectation of privacy" in automobiles was dictum. See id. at 591-92 (upholding warrantless taking of tire tread impressions and paint scrapings from car's exterior on ground that defendant had no expectation of privacy with regard to his car's exterior). Justice Blackmun expressly limited his holding to automobile exteriors, stating that he did not intend "to say that no part of the interior of an automobile has Fourth Amendment protection." Id. at 591. Finally, the only support Justice Blackmun offered for the notion of "lesser" privacy in automobiles was Justice Powell's concurrence in AlmeidaSanchez v. United States, 413 U.S. 266, 279 (1973), see note 54 supra, and an arcane 1922 state court decision, People v. Case, 220 Mich. 379, 190 N.W. 289, that had relied on pre-Katz notions to hold that "[t]he automobile is a swift and powerful vehicle of recent development" whose "active use is not in homes nor on private premises, the privacy of which the law especially guards." $220 \mathrm{Mich}$. at 388 , 190 N.W. at 292. The opinion in People v. Case was subsequently declared "thoroughly vitiated" by the Michigan Supreme Court. People v. Ubbes, 374 Mich. 571, 594, 132 N.W.2d 669, 681 (opinion of Souris, J.) (1965). It should be noted that sociological evidence belies a generalized finding that automobile owners do not expect much privacy in their vehicles. See note 140 infra.

57. See, e.g., Wilson, The Warrantless Automobile Search: Exception Without Justification, 32 HASTINGS L.J. 127, 129-30, 158-62 (1980); Yackle, supra note 37, at 404-415; Note, Warraniless Searches and Seizures of Automobiles, 87 HARV. L. REV. 835, 840-41 \& n.28 (1974); Comment, The Automobile Exception: A Contradiction in Fourth Amendment Principles, 17 SAN DIEGo L. REV. 933, 936 (1980). 
ued to rely on this lesser expectation analysis to uphold non-exigent, warrantless vehicle searches..$^{58}$

Counterposed to these automobile cases are the more recent decisions in United States v. Chadwick ${ }^{59}$ and Arkansas v. Sanders. ${ }^{60}$ These cases hold that warrantless searches of luggage are impermissible in non-exigent circumstances because "a person's expectations of privacy in personal luggage are substantially greater than in an automobile." 11

Although the Court has not straightforwardly contrasted the underlying analyses of these luggage and automobile decisions, the holdings appear to indicate that the Court has implicitly identified two points on a hierarchical scale of privacy interests, placing those attributed to automobiles near one end and those associated with luggage nearer the other. ${ }^{62}$ "Lesser" expectations of privacy are not protected by the warrant requirement, while "greater" expectations are fully protected from warrantless intrusion. Although the Supreme Court has explicitly employed this analysis only in cases involving automobiles, ${ }^{63}$ lower courts have applied the lesser

58. See Robbins v. California, 101 S. Ct. 2841,2845 (1981) (plurality opinion) (referring with approval to the "automobile exception . . . supported by "the diminished expectation of privacy which surrounds the automobile" ") (quoting United States v. Chadwick, 433 U.S. 1, 12 (1977)).

59. 433 U.S. 1 (1977) (holding warrantless search of lawfully seized, locked 200-lb. footlocker unconstitutional).

60. 442 U.S. 753 (1979) (hoiding warrantless search of lawfully seized, unlocked suitcase unconstitutional).

61. Chadwick v. United States, 433 U.S. 1, 13 (1977); accord, Arkansas v. Sanders, 442 U.S. 753, 761 (1979).

62. For other decisions implying this conclusion, see Robbins v. California, 101 S. Ct. 2841, 2850 n.3 (1981) (Powell, J., concurring) (dividing containers into three groups for purposes of Fourth Amendment analysis: those "inevitably associated with expectations of privacy;" those that "consistently lack such an association;" and "ambigous" containers "in the middle"); Walter v. United States, 447 U.S. 649, 658 (1980) ("securely wrapped" cartons are subject to warrant requirement because owners had no "lesser expectation of privacy than the [owner] of an ordinary locked suitcase"); $c f$. Recent Development, 55 WASH. L. REV. 871, 882 (1980) (speculating that Sanders decision may indicate that "the Court anticipates some gradation of the privacy interest in various containers and packages").

63. But cf. Michigan v. Summers, 101 S. Ct. 2587, 2592 (1981) (upholding standard of less than probable cause for warrantless detention of persons on premises of house about to be searched pursuant to search warrant, because such seizures constitute "limited intrusions on the personal security of those detained"); Bell v. Wolfish, 441 U.S. 520, 557 (1979) (upholding warrantless searches of pretrial detainees based in part on "diminished expectation of privacy" in custodial facilities and in part on special conditions present in criminal detention process).

In Robbins v. California, 101 S. C. 2841 (1981), the Court exhibited indecision with regard to extending the lesser expectation of privacy analysis to other areas. $\Lambda t$ issue was the non-exigent, warrantless search of irregularly-shaped packages seized from an automobile luggage compartment and wrapped and taped shut in opaque plastic. $\Lambda$ plurality of four Justices held the search unconstitutional, agreeing that all "closed, opaque containers" mainfest constitutionally protected privacy interests and thus apparently rejecting the lesser expectations approach. Id. at 2846. Chief Justice Burger concurred in the judgement without opinion. Id. at 2847. Concurring, Justice Powell explicitly advocated applying a hierarchical privacy scale. Id. at 2850; see note 62 supra (quoting from Justice Powell's concurring opinion). Finally, three Justices dissented in separate opinions, all apparently rejecting a hierarchical approach and advocating a bright-line rule permitting a warrantless search of any containers discovered in a lawfully seized and searchable automobile. See id. at 2581 (Blackmun, J., dissenting); id. at 2853 (Rehnquist, J., dissenting); id. at 2855 (Stevens, J., dissenting). Lower 
expectations approach to searches of other objects and areas, with confused and conflicting results. ${ }^{64}$

The court has offered little explanation for its decision to forego the warrant requirement in non-exigent automobile searches, other than the bald assertion that the privacy interests affected are relatively minor. ${ }^{65} \mathrm{By}$ failing to identify any countervailing societal needs served by the lesser expectation of privacy exception, the Court has violated the settled Fourth Amendment doctrine that exceptions to the warrant requirement are permitted only to accomodate the "identified needs of society," government must bear the burden of proving that an exception is necessary. ${ }^{67}$

courts have disagreed over how the Robbins decisions should be interpreted. Compare United States v. Weber, 664 F.2d 841, 851 \& n.7 (1st Cir. 1981) (upholding Robbins closed opaque container rule, on view that Justice Powell alone supported hierarchical approach) and United States v. Monclavo-Cruz, 662 F.2d 1285, 1287 \& n.1 (9th Cir. 1981) (same) with United States v. Martino, 664 F.2d 860, 87273 (2d Cir. 1981) (adopting Justice Powell's hierarchical approach as "holding" of Robbins, because it represented narrowest ground of majority opinions). The Supreme Court may clarify its views regarding a hierarchical approach to privacy protection under the Fourth Amendment in the 1981 term, in Ross v. United States, 655 F.2d 1159 (D.C. Cir.) (en banc), cert. granted, 102 S. Ct. 386 (1981) (appeal from holding that warrant requirement applies to paper bag lawfully seized from automobile, parties "directed to address the question whether the Court should reconsider Robbins").

64. Most commonly the lesser expectations approach has been applied to reviews of warrantless searches of containers. See notes 104, 105 \& 132 infra ( noting conflicting container search decisions). Courts have also applied the analysis to searches of areas such as scientific laboratories, see United States v. Buettner-Janusch, 646 F.2d 759, 766 (2d. Cir.), cert. denied, 102 S. Ct. 126 (1981), vessels at sea, see United States v. Ortega, 644 F.2d 512, 514-15 (5th Cir. 1981), and commercial premises at night, see Alaska v. Myers, 601 P.2d 239, 242-43 (Alaska 1979).

65. The Court has hinted that difficulties surrounding seizure and storage of automobiles due to their size might also support an automobile exception. See Arkansas v. Sanders, 442 U.S. 753, 765-66 n.14 (1979) (strict warrant requirement for lawfully seized automobiles might create "severe, even impossible, burdens on many police departments" by making necessary adequate towing equipment, safe storage lots, and extra personnel). But see Comment, supra note 57, at 954 (police departments may in fact have adequate facilities for temporary automobile impoundment while warrants are sought). If the Court intends to rely on the Sanders dictum, however, it has so far failed to say so explicitly, and has rested its distinction between automobiles and luggage solely on supposed privacy differences. See p. 322-24 supra. Moreover, even if such practical difficulties may be held to support a general automobile exception, the reasoning fails to distinguish luggage from other, smaller containers that lower courts have held excepted from the warrant requirement. See notes $104 \& 132$ infra (citing cases).

66. Arkansas v. Sanders, 442 U.S. 753, 760 (1979); $c f$. United States v. Chadwick, 433 U.S. 1, 15 (1977) (warrant is required whenever "no exigency is shown to support the need for an immediate search").

67. The lack of demonstrated justification for a lesser expectation of privacy exception to the warrant requirement forces defendants to demonstrate not only that their privacy has been invaded, but also that their interest in that privacy rises to some undefined level of intensity or importance, in order to be fully protected by the Fourth $\Lambda$ mendment. Although the Supreme Court noted in Rakas v. Illinois, 439 U.S. 128 (1979), that the "proponent of a motion to dismiss has the burden of establishing that his own Fourth Amendment rights were violated," id. at 130-31 n.1, this merely "reaffirmed the established rule" that a defendant must show that "challenged conduct invaded his legitimate expectation of privacy rather than that of a third party." United States v. Payner, 447 U.S. 727, 731 (1980). Thus the government should still have to justify warrantless intrusions on personal privacy. Several respected jurists have noted the implicit break with settled doctrine that an unjustified lesser expectation of privacy exception entails. See, e.g., United States v. Ross, No. 79-1624, slip op. at 3 (D.C. Cir. April 17, 1980) (Bazelon, J., dissenting), rev'd en banc, 655 F.2d 11, cert. granted, 102 S. 
Moreover, the recognition of lesser expectations of privacy cannot be dismissed simply as an implicit holding that certain expectations of privacy are "unreasonable." If this were the case, the Court could simply hold that such expectations fall completely outside the scope of the Fourth Amendment and are therefore wholly unprotected. The Court has steadfastly maintained, however, that individuals do retain privacy interests in their automobiles, ${ }^{68}$ and continues to judge automobile searches according to the Amendment's reasonableness and probable cause standards. The inescapable conclusion is that the Court is recognizing a new exception to the warrant requirement sub silentio, uniquely grounded not on exigent necessity or other demonstrable societal need, but solely on the perceived insignificance of certain types of privacy interests. ${ }^{69}$

\section{A Critique of Current Privacy Analysis}

The expectation of privacy approach to claims under the Fourth Amendment may be criticized on three general grounds. First, using a concept of "reasonable expectations" to identify privacy confuses analysis and permits manipulation of privacy protection. Second, a single valueordered hierarchy of privacy interests that is fair cannot be developed, and would be unworkable in any case. Finally, a Fourth Amendment analysis that denies warrant protection to those privacy interests labeled "lesser" merely because the warrant process involves some cost to law enforcers is constitutionally impermissible.

Ct. 386 (1981) (panel takes "entirely novel approach" because "[i]nstead of requiring those seeking an exemption from the warrant requirement to show the need for one, the majority would ask the defendant . . . to demonstrate . . that his personal possessions should be entitled to the protection of the Fourth Amendment"); United States v. Mackey, 626 F.2d 684, 688 (9th Cir, 1980) (Tang, J., dissenting) (by presuming that burden is on defendant in paper bag search case, majority "inverts . . . the correct analytic approach").

68. See Delaware v. Prouse, 440 U.S. 648, 662 (1979) (" $A$ n individual operating or traveling in an automobile does not lose all reasonable expectation of privacy."); United States v. Ortiz, 422 U.S. 891,896 (1975) (" $\Lambda$ search, even of an automobile, is a substantial invasion of privacy."); $c f$. Coolidge v. New Hampshire, 403 U.S. 443, $461-62$ (1971) (plurality opinion) ("The word 'automobile' is not a talisman in whose presence the Fourth Amendment fades away and disappears.")

69. Cf. United States v. Ross, 655 F.2d 1159, 1169 (D.C. Cir. 1981) (en banc), cert. granted, 102 S. Ct. 386 (1981) (by secking warrant exception for "unworthy containers" based on lesser expectations of privacy, "the prosecution asks, in essence, that we delineate a new exception").

The possibility of basing Fourth Amendment protection on a hierarchical conception of privacy has been brielly noted but rejected out of hand in the past. See, e.g., South Dakota v. Opperman, 428 U.S. 364, 386 (1976) (Marshall, J., dissenting) (criticizing majority for appearing to suggest that automobiles may be warrantlessly searched for "less compelling" reasons than may houses due to a "'diminished' expectation of privacy," and declaring that "[t]his has never been the law"); Weinreb, supra note 24, at 70, 75 ("[i]f one took seriously" Court's decisions regarding non-exigent warrantless automobile searches, they could support "doctrine of degrees of privacy," but "[c]onstitutionally, there are no degrees of privacy"). 


\section{A. Abandoning Reasonable Expectations in Favor of Privacy Interests}

The explicit focus on privacy in Katz represented an important advance in Fourth Amendment analysis. ${ }^{70}$ Nevertheless, Justice Harlan's reasonable expectation of privacy formula has become a manipulable and restrictive analytical tool for identifying privacy concerns that fall within the Amendment's protective scope. ${ }^{71}$ A pure concept of privacy interests based upon an objective definition of privacy should instead be the focus of Fourth Amendment analysis.

\section{The Problem with Reasonable Expectations}

Initially, the reasonable expectation of privacy test requires an individual to have an "actual expectation" of privacy before he can claim Fourth Amendment protection. ${ }^{72}$ Expectations of privacy, however, are not necessarily coextensive with privacy per se. Critics have noted that such subjective perceptions can be manipulated by the government; in various Orwellian $^{73}$ hypotheticals, persons might not actually expect privacy in circumstances where a normative interest in privacy is clearly identifiable. ${ }^{74}$ Conversely, an irrational individual might actually expect privacy in situations where no true privacy claim can be said to exist.

70. The value of Katz has been well-noted. See Amsterdam, supra note 21, at 383, 385 (Katz is "seminal" and "important for its rejection of several limitations upon the operation" of Fourth Amendment); Note, The Reasonable Expectation of Privacy-Katz v. United States, $A$ Postscriptum, 9 IND. L. REV. 468, 498 (1976) [hereinafter cited as Postscriptum] (Katz a "milestone" because it enabled "legal protection to conform to changing times and technology"); Note, supra note 42, at 1470 (insofar as Katz freed privacy protection from property concepts, it represents "an extension of Fourth Amendment protection").

71. See Amsterdam, supra note 21, at 385 (rejecting "talismanic" application of expectation of privacy analysis, because it does not offer "comprehensive test of fourth amendment coverage"); Dworkin, Fact Style Adjudication and the Fourth Amendment: The Limits of Lawyering, 48 IND. L. J. 329, 335 (1973) (expectations test is "severe restriction on the scope of fourth amendment protection"); see also note 21 supra (listing critical commentators of reasonable expectation of privacy test); cf. Postscriptum, supra note 70, at 498 ("redefinition" of Fourth $A$ mendment privacy analysis may be necessary after Katz, due to "abstractness" of reasonable expectation of privacy test).

72. See p. 316 supra (describing reasonable expectation of privacy formula).

73. See G. ORIWELL, NINETEEN EIGHTY-FOUR 4 (1949):

There was of course no way of knowing whether you were being watched at any given moment. . . . It was even conceivable that they watched everybody all the time. . . . You had to live-did live, from habit that became instinct-in the assumption that every sound you made was overheard, and . . . every movement scrutinized.

74. See Amsterdam, supra note 21, at 384 (state might eliminate expectations of privacy by making pervasive television announcements that all citizens were "forthwith being placed under comprehensive electronic surveillance"); Note, supra note 21, at 158 (hypothesizing "well publicized" statute that would require "occupants of automobiles on toll highways to submit to extensive searches of the[ir] vehicles, their persons, and their luggage at selected toll booths"). Such hypotheticals do not seem so far-fetched in light of recent decisions holding that certain expectations of privacy may be reduced or eliminated by statute or posted notice. See, e.g., United States v. Williams, 617 F.2d 1063, 1087 (5th Cir. 1980) (en banc) ("[E]xtensive federal and international regulation of shipping and boating significantly limits the privacy that anyone might expect to have on the seas."); Gillett v. State, 588 S.W.2d. 361, 363 (Tex. Crim. App. 1979) (en banc) (posted notice that department store 
Anticipating the latter possibility, the test also requires that actual expectations be "reasonable" to be protected. In practice, courts often simply presume the existence of an actual expectation and devote their energies to this second inquiry for reasonableness, making the question of actual expectations totally academic. ${ }^{75}$ But to define reasonable expectations as those which "society is prepared to accept as reasonable" is obviously tautological ${ }^{76}$ and makes the entire analysis essentially standardless. ${ }^{77}$ For these reasons, the notion of reasonable expectations of privacy should be abandoned in favor of a pure concept of "privacy interests," in the sense of claims to privacy to which persons are entitled under the Fourth Amendment regardless of individual expectations. ${ }^{78}$

\section{Defining Privacy}

For all its modern concern with privacy, the Supreme Court still has not arrived at a common, workable definition of privacy. ${ }^{79}$ Nevertheless, in

fitting rooms were "under surveillance" eliminated any expectation of privacy of occupants).

Four years after Katz, Justice Harlan dissociated himself from an application of his own reasonable expectation of privacy test on this very ground. See United States v. White, 401 U.S. 745, 786 (1971) (Harlan, J., dissenting) ("analysis must, in my view, transcend the search for subjective expectations" because "expectations . . . are in large part reflections of laws"). The Supreme Court has more recently noted the possibility of undesirable manipulation of privacy protection under the "expectations" approach, but has advanced no helpful solution. See Smith v. Maryland, 442 U.S. 735, 740-41 n.5 (1979) (commenting only that if "individual's subjective expectations had been 'conditioned" by influences alien to well-recognized Fourth Amendment freedoms, . . . a normative inquiry would be proper").

75. See, e.g., Smith v. Maryland, 442 U.S. 735, 743 (1979) ("[E]ven if petitioner did harbor some subjective expectation that the phone numbers he dialed would remain private, this expectation is not 'one that society is prepared to recognize as reasonable.' "); United States v. Ramapuram, 632 F.2d 1149, 1155 (4th Cir. 1980), cert. denied, 101 S. C. 1739 (1981) ("We assume that Ramapuram had an actual subjective expectation of privacy".); $c$. Amsterdam, supra note 21, at 384 (actual expectation of privacy "can neither add to, nor can its absence detract from, an individual's claim to fourth amendment protection").

76. Cf. Amsterdam, supra note 21, at 385 ("[T] fourth amendment protects those interests that may justifiably claim fourth amendment protection. Of course this begs the question.")

77. Numerous critics have noted that the reasonable expectation of privacy test provides "no objective referent" to guide courts or police. Note, supra note 42, at 1474. See, e.g., Walinski \& Tucker, supra note 21, at 2 ("no principled way for judges to determine whether a given expectation of privacy" is reasonable); Yackle, supra note 37, at 362 ("[T]here is no more amorphous standard in our law than 'reasonableness' . . . . The inquiry is unprincipled.")

78. Cf. Amsterdam, supra note 21, at 384 (Fourth Amendment rights are not merely subjective expectations; they are rights that "we should demand of government"); Note, supra note 21 , at 171 (if "expectations" are to determine Fourth Amendment's scope, then "courts must recognize that the core of the fourth amendment contains a minimum set of expectations to which all persons are entitled").

$\Lambda \mathrm{n}$ "interest" in constitutional law generally is recognized as representing a claim to some right, in the sense of an entitlement, as in "liberty interest," or "property interest." See BLACK's LAW DIC. TIONARY 729 (5th ed. 1979) (defining "interest" as "the most general term that can be employed to denote a right, claim, title, or legal share in something"). A "privacy interest," then, is a claim that one has privacy or is entitled to have privacy in a particular place or situation; such a claim should not be dependent on individual subjective desire.

79. Most of the Supreme Court's pronouncements on privacy have come in abortion or sexual conduct cases, and have been exemplary rather than explanatory. See, e.g., Maher v. Roe, 432 U.S. 
order to give the concept of privacy interests meaningful content for protection of privacy under the Fourth Amendment, the law must reach some agreement as to what constitutes privacy. ${ }^{80}$ Such a definition should not be left open for individual courts to fill on a case-by-case basis; ${ }^{81}$ some common, objective definition of privacy must be developed if the concept of "privacy interests" is to be any less manipulable than that of "expectations." "82

The essence of privacy is twofold: the ability to keep personal information unknown to others and to keep one's self separate from interaction with others. These basic concepts, which embody the definitions of privacy proffered by experts in divers fields, can be encapsulated in the phrase "secrecy and solitude." The Fourth Amendment's restrictions on searches and seizures may in fact be viewed as limitations on the govern-

464, 472-73 (1977) ("personal privacy" includes "woman's freedom of choice" regarding pregnancy and abortion); United States v. Orito, 413 U.S. 139, 142 (1973) (listing "privacy rights such as those of marriage, procreation, motherhood, child rearing and education"); Griswold v. Connecticut, 381 U.S. 479, 486 (1965) (right to privacy includes "notions of privacy surrounding the marriage relationship"). See also pp. 313-14 supra (discussing constitutional status of privacy).

In Katz v. United States, 389 U.S. 347 (1967), the Court defined a "ggeneral right to privacy," (as opposed to the specific privacy guarantees under the Fourth $\Lambda$ mendment), as "the right to be let alone by other people." Id. at 350; cf. Warren \& Brandeis, The Right to Privacy, 4 HARV. L. REV. 193, 193, 195 (1890) (discussing right to privacy as the "right to be let alone"). The Court has not further developed a definition of privacy in the Fourth $A$ mendment context, however, because since Katz its analysis has focused on reasonable expectations instead of on privacy itself.

80. Cf. Note, Toward a Constitutional Definition of Religion, 91 H^RV. L. REV. 1056, 1056 (1978) ("before courts apply any of the standards developed to effectuate the first amendment, they must" develop some definition of religion and religious belief). Some commentators have suggested that privacy may be undefinable. Sec, e.g., Gerety, Redefining Privacy, 12 H^rv. C.R-C.L. L. REv. 233, 234 (1977); Kurland, The Private I, U. CHI. MAG., Autumn, 1976, at 7, 12. A workable definition must be attempled, however, as these same commentators have gone on to do, unless privacy analysis under the Fourth Amendment is to be abandoned.

81. The danger of allowing individual courts to decide what constitutes a reasonable expectation of privacy without giving them objective guidelines is that "[a]s the judges' own values vary, so does the scope of the Fourth Amendment." Note, supra note 21, at 1474.

82. Furthermore, law enforcement officers cannot be expected to understand and consistently apply Fourth Amendment privacy analysis without some objective guidelines. Cr. Parker, A Definition of Privacy, 27 RUTGERS L. REV. 275, 276-77 (1974) (any definition of privacy should be judged under three criteria: accurate data-fit, simplicity, and "applicability by lawyers and courts").

83. See, e.g., I. ALTMAN, supra note 5, at 20 ("selective control of access to the self or to one's group"); $\Lambda$. WESTIN, supra note 5, at 7 (individuals' ability "to determine for themselves when, how, and to what extent information about them is communicated to others," and to control their "voluntary and temporary withdrawal" from society); Gavison, supra note 5, at 428 ("secrecy, anonimity, and solitude"); Laufer \& Wolfe, supra note 43, at 23 ("management of interaction . . . and information"); Marshal, Privacy and Environment, 1 HUMAN ECOLOGY 93, 93 (1972) ("ability to control the degree to which people and institutions impinge upon one's life"); Scanlon, Thomson on Privacy, 4 PHIL. \& PUB. AFF. 315, 326 (1975) ("our ability to control who has access to us and to information about us"); Note, supra note 57, at 841 (automobile searches involve intrusions upon "privacy as secrecy"). But $c f$. Shils, supra note 43 , at 283 n.1 (secrecy can be distinguished from privacy on ground that concept of privacy allows for voluntary disclosure of information while secrecy does not). All legal defintions of privacy, including that suggested here, owe some debt to Warren \& Brandeis' seminal discussion of privacy in the libel context as the "right to be let alone." See Warren \& Brandeis, supra note 79, at 193. 
ment's right to intrude upon secrecy and solitude respectively. ${ }^{84}$ Such a conjunction of the legal and social science concepts of privacy is desirable, and "secrecy and solitude" may therefore be adopted as the starting point for a broad yet more objective constitutional definition of privacy. ${ }^{85}$ With this embryonic definition in mind, courts should view any governmental violation of an individual's control over personal information or interaction with others as an infringement of Fourth Amendment privacy interests. ${ }^{86}$

\section{B. Hierarchical Privacy: Undesirable and Unworkable}

Once privacy interests are identified, Fourth Amendment analysis must provide a rubric for applying the protections of the Amendment to those interests in particular circumstances. The hierarchical approach of the lesser expectations of privacy rationale, despite its apparent sophistication, ${ }^{87}$ creates a system of Fourth Amendment analysis that is unworkable and discriminatory. Moreover, an exception to the warrant requirement based solely upon warrant costs ignores the constitutional balance struck in the Fourth Amendment, and is therefore unacceptable.

84. With regard to secrecy, see, e.g., Arkansas v. Sanders, 442 U.S. 753 (1979) (protecting secrecy of contents of closed suitcase); Katz v. United States, 389 U.S. 347 (1967) (protecting secrecy of telephone calls made from public phone booth); Ex parte Jackson, 96 U.S. 727, 733 (1878) (protecting "secrecy of letters and . . . sealed packages"). With regard to solitude (i.e., interaction with government agents), see, e.g., Delaware v. Prouse, 440 U.S. 648, 653 (1979) (police stop of automobile is Fourth $\Lambda$ mendment "seizure" even though "quite brief"); Terry v. Ohio, 392 U.S. 1, 16 (1968) ("whenever a police officer accosts an individual and restrains his freedom to walk away, he has 'seized' that person" for Fourth Amendment purposes).

85. Defining privacy as secrecy and solitude helps to objectify the concept because the two component interests, personal information and interaction with others, have relatively concrete meanings and are therefore capable of objective definition. Hence these interests will be more immediately and consistently identifiable by large numbers of individuals, including judges, law enforcement officers, and the average citizen. An element of subjectivity undeniably remains in this definition; this is, however, the inherent difficulty in any definitional process, especially one concerning constitutional concepts, and it should not forestall the attempt. See Gerety, supra note 80, at 236 \& nn.14-16 (definition of privacy must rest on subjective intuitions at some level, but, as with all intuitions, "if enough people share them ... . we say we know them to be so"); cf. Note, supra note 80, at 1072 (search for constitutional definition of religion is "inherently problematic" due to unavoidable recourse to "inductive reasoning").

86. Infringement of a privacy interest merely triggers further Fourth Amendment analysis, see pp. 337-38, and does not necessarily lead to full Fourth Amendment protections. See pp. 320-21 supra (discussing exceptions to full Fourth Amendment protection); cf. p. 315 supra (Fourth Amendment analysis is two-step process).

87. See pp. 322-26 supra (discussing lesser expectation of privacy approach to Fourth Amendment analysis). To the extent that the lesser expectations approach identifies obvious rough distinctions among privacy interests, see p. 332 infra, and permits intermediate levels of Fourth Amendment protection, it may appear more sophisticated than the simple dichotomy between reasonable and unreasonable expectations of privacy. Because results under this approach are unfair, unworkable, and constitutionally impermissible, however, see pp. 331-36 infra, its apparent sophistication is only skindeep. 


\section{A New Implicit Balance}

Because the exception to the warrant requirement for "lesser" privacy interests is only now emerging, its theoretical foundation can only be surmised. Given that the Supreme Court has failed to assert any compelling societal need as a counterbalance to the privacy interests that are infringed under this approach, ${ }^{88}$ it appears that the underlying analysis weighs the bare cost of the warrant process itself against privacy. ${ }^{89}$ Apparently, privacy interests judged to be less "valuable" than the cost of a warrant are excepted from the warrant requirement. If warrant costs are in fact being viewed as the implicit counterbalance to "lesser" privacy interests, the analysis represents a significant break with past Fourth Amendment doctrine. The Supreme Court has consistently held that the cost of the warrant process should not affect the Fourth Amendment balance; warrants are "not an inconvenience to be somehow 'weighed' against ... police efficiency." "90

\section{A Privacy Hierarchy-Neither Workable Nor Fair}

There are several reasons to believe that a privacy hierarchy that discriminates between privacy interests of "lesser" and "greater" importance or value will be unfair and unworkable in practice. First, privacy is a culturally diverse concept, ${ }^{91}$ and it is unlikely that a single fair hierarchy of privacy concerns can be developed. Individuals placed in different environments develop varying conceptions of privacy that are compatible with

88. See p. 325 supra (Supreme Court has not identified any counterbalancing need to justify a lesser expectation of privacy exception to warrant requirement). It must not be forgotten that privacy interests are actually identified and held affected in cases that employ the "lesser interest" approach. See p. 326 supra (Supreme Court continues to hold that privacy interests in automobiles are significant).

89. Cf. United States v. Ross, 655 F.2d 1159, 1170 (D.C. Cir.) (en banc), cert. granted, 102 S. C. 386 (1981) (speculating that "the argument [for lesser expectation of privacy exception] appears to be that" some privacy claims "are too small, [or] too insecure ... to burden the time of a magistrate").

90. Coolidge v. New Hampshire, 403 U.S. 443, 481 (1971); see note 115 infra (citing cases in accord).

91. Professor Altman has argued that the desire and capability to achieve and regulate privacy is a "cultural universal," common to human beings in all settings. Altman, Privacy Regulation: Culturally Universal or Culturally Specific? 33 J. SOC. IssuES 66, 68, 82 (1977). Accord, A. WESTIN, supra note 4, at 13 ("Needs for individual and group privacy and resulting social norms are present in virtually every society.") Although the universality of the human need and desire for privacy is undeniable, specific conceptions of what constitutes a desirable level of privacy and how to achieve it vary both among and within cultures, creating "cultural diversity" for purposes of comparing specific privacy interests. See Altman, supra, at 67-68, 69 ("a person may use different [privacy regulating mechanisms], depending upon circumstances" and "specific behaviors and techniques used to [regulate privacy] may be quite different from culture to culture"); id. at 72-82 (giving examples of different cultural privacy conceptions from areas such as Brazil, Africa, and South Pacific); $\Lambda$. WESTIN, supra note 4, at 11-18, 26-30 (giving cross-cultural examples); see generally E. H $\Lambda$ LL, THE HIDDEN DIMENSION 123-67 (1966) (discussing different cross-cultural and intra-cultural conceptions of privacy). 
prevailing conditions. ${ }^{92}$ If the manifestations of such diverse privacy conceptions effectively preserve privacy, however, they cannot be said to be objectively wrong, unreasonable, or "less valuable" to their holders. ${ }^{93}$

Any attempt to rank claims to privacy in order of their relative importance will therefore vary according to the ranker's conception of privacy, and no unitary scale can be developed without slighting others that may be equally valid. ${ }^{94}$ While rough distinctions among privacy interests may possibly be made on a general level (for example, that automobiles are generally held to be less private places than houses), the importance of privacy to different individuals in particular circumstances cannot readily be generalized nor predicted..$^{95}$ If the privacy hierarchy preferred by the majority is chosen as the constitutional standard for Fourth Amendment analysis, identifiable privacy interests of nonconforming minorities will in-

92. See I. ALTMIAN, supra note 4 , at 32 ("IP]rivacy mechanisms can change over time and are responsive to the situation at hand."); Laufer \& Wolfe, supra note 43, at 25 (same); Marshall, supra note 83, at 95 (same). Privacy conceptions will be varied rather than absent in conditions that are adverse to secrecy and solitude because privacy is a fundamental human need. See note 4 supra (discussing importance of privacy). Examples of privacy conceptions that differ from those of the majority of Americans are those held by the poor, see, e.g., I. ALTMAN, supra note 4, at 38 (indigent couple achieved privacy from seven children by placing marital bed behind "wall built out of empty crates"); G. SUTTLES, THE SOCIAL ORDER OF THE SLUM 78, 91 (1968) (poor have a "homelife that allows for little privacy" yet have street life of a "highly personal and private nature"), and by the mentally ill, see, e.g., E. GOFFMAN, ASYLUMS 230-37, 246, 251-52 (1961) (residents of mental hospital sought privacy in "underground trench," "partly wooded field," "dark alcove," and beneath blankets on floor, and concealed their personal possessions in jacket pockets, shopping bags, socks, and a "cleanedout tobacco pouch"); Bettelheim, Feral Children and Autistic Children, 64 AM. J. SOC. 455, 458 (1959) (autistic children "build themselves dens in dark corners or closets" by using blankets).

93. Whether privacy is "effectively preserved" in a particular situation will require an objective examination of the circumstances for secrecy or solitude. See pp. 329-30 supra. Although a particular privacy claim or mechanism may seem bizarre to other individuals, it is objectively valid if it has preserved some degree of secrecy or solitude even in a tenuous manner. Cr. I. ALTMAN, supra note 4, at 38 (example of bedroom wall made of orange crates).

94. Cf. K. ARROW, SOCIAL GHOICE AND INDIVIDUAL VALUES 59 (2d ed. 1963) ("[M]ethods of passing from individual tastes to social preferences ... are either imposed or dictatorial."); Michelman, Political Markets and Community Self-Determination: Competing Judicial Models of Local Government Legitimacy, 53 IND. L.J. 145, 157 n.48 (1978) (noting "logical impossiblity of there being some such procedure or formula for combining individual preference orderings so as to get determinate and consistent social preference orderings").

95. Thus in a particular situation an individual may value the privacy of his automobile more than that available in his home, and entire classes of people, such as residents of crowded tenements, may value their automobiles far more than their apartments as private places. See Yackle, supra note 37, at 410-411 (1978) (suggesting examples of persons who place high value on the privacy of their motor vehicles: "family that lives in a mobile home or . . . a recreational vehicle," "traveling salesperson," and persons "who live in over-crowded apartments where the television set is always blasting, the phone is always ringing, and the kids are always screaming"). Even if the lesser interests approach permitted individuals with differing privacy hierarchies to demonstrate that their specific privacy interests are "important enough" to receive full Fourth Amendment protection, it would constitute an unexplained shifting of the burden of proof from the government on whom that burden traditionally lies. See note 67 supra (noting implicit burden shift under lesser interests approach). The cost of individualized hearings to determine the status of privacy claims also argues against such an approach. 
evitably be impinged upon as "lesser," ${ }^{396}$ an unfair and undesirable result in a constitutional system that generally respects minority rights. ${ }^{97}$

In addition, income level variations among members of society make it likely that an analysis that slights lesser privacy interests will adversely affect the poor. ${ }^{98}$ Some commentators have suggested that the precautions taken to preserve privacy should be looked to when evaluating which privacy interests are reasonable or important enough to merit full Fourth Amendment protection. ${ }^{99}$ The poor, however, are less able to afford precautions that might serve as such indicators, ${ }^{100}$ and therefore would be more likely to be subjected to intrusions than would wealthy individuals. Consequently, as Judge Bazelon has noted with regard to container searches, the lesser interests approach "makes the level of constitutional protection available to a citizen dependent on his ability to purchase a fancy repository for his belongings."101 A constitutional analysis that sys-

96. Cf. United States v. Moschetta, 646 F.2d 955, 961 n.9 (5th Gir. 1981) ("[S]ome people in our society do use paper sacks . . . for receptacles of personal effects, even if the majority do not. Any new expectation of privacy analysis which in effect [fails to protect such containers] necessarily implies the denigration of the privacy interests of such people."); Amsterdam, supra note 21, at 404 (people who live in private homes "tend to take a rather parochial view of privacy" and "denigrate the importance of degrees of privacy" to "ghetto flat" residents).

97. Thus, as in the parallel area of religious freedom under the First Amendment, conceptions of privacy are radically pluralistic, and "[i]f there is any fixed star in our constitutional constellation, it is that no official . . . can prescribe what shall be orthodox." West Va. Bd. of Educ. v. Barnette, 319 U.S. 624, 642 (1943). Cf. Note, supra note 80, at 1072 (danger of subjective definition of religion is "that courts will determine what is or is not religion on the basis of their own parochial experience," resulting in "arbitrary exclusion of the unorthodox").

98. This second criticism should be differentiated from the criticism that a hierarchical privacy system will discriminate against nonconforming minorities. Not all nonconforming minorities are poor, and the approach discriminates in this second way because the particular minority is poor, not merely because it fails to conform.

99. See Rakas v. Illinois 439 U.S. 128, 152 (1978) (Powell, J., concurring) (court should examine whether individual "took normal precautions to maintain his privacy"); Note, supra note 42, at 148084 (courts should examine whether means used to secure privacy are "reasonably calculated to acheive that purpose"). Although a "reasonable precautions" focus may sharpen the reasonable expectation of privacy test somewhat, see id. at 1480-81, it obviously does not avoid the subjectivity inherent in any "reasonableness" approach, and may result in a failure to protect privacy in situations where precautions are unavailable to an individual or are seemingly unnecessary. See Note, supra note 21, at 169 (precautions focus offers "no refinement of 'reasonableness' concept," and fails in circumstances where "taking precautions . . . is either unduly burdensome . . . or wholly inconsistent with basic notions of individual autonomy"); Note, Katz and the Fourth Amendment: A Reasonable Expectation of Privacy or, A Man's Home is His Fort, 23 CLEv. ST. L. REV. 63, 66-72 (1974) (taken to logical extreme, precautions focus could result in Fourth Amendment protection only for hermit-like occupants of windowless, soundproof forts).

100. See Katz, Patterns of Arrest and the Dangers of Public Visibility, 9 CRIM. L. BULl. 311, 320 (1973) (wealthy persons can better afford "private facilities" equipped with "locks, doors, curtains, gates, [and] fences" than can the poor); Shulman, Bag Ladies, The New York Times, Sept. 29, 1981, at A27, col. 1 ("[W]hile most of us have drawers [and] closets . . . in which to store our possessions, the homeless . . . have only their shopping bags.")

101. United States v. Ross, No. 79-1624, slip op. at 10 (D.C. Cir. Apr. 17, 1980) (Bazelon, J., dissenting), rev'd en banc 655 F.2d. 1159, cert. granted, 102 S. Ct. 386 (1981). As the en banc majority in Ross noted, an exception to the warrant requirement for containers alleged to have lesser privacy interests "would snare those without the means or the sophistication to use worthy containers." 655 F.2d at 1170. 
tematically tends to deprive the poor of a fundamental right such as privacy is not only undesirable, but also constitutionally impermissible. ${ }^{102}$

Finally, the infinite variety of circumstances possible in search and seizure cases, combined with the inherent subjectivity of a hierarchical privacy analysis as outlined above, makes a lesser interests approach to Fourth Amendment analysis unworkable. Every case presents a unique set of facts that may be relevant to the determination of the status of a privacy claim, and courts have failed to develop discernible standards by which consistent determinations can be made. ${ }^{103}$ Consequently, in reviewing various container searches, some courts have found that a knapsack, zippered and unzipped carrying bags, a cardboard box, and a closed paper bag all manifest privacy interests that are insufficient to merit warrant protection. ${ }^{104}$ Other courts have come to the opposite conclusion in cases involving virtually identical containers. ${ }^{105}$ While case-by-case adjudication might eventually produce relatively consistent guidelines in some areas of law, this has never been the case in the Fourth Amendment context. ${ }^{106}$

102. Poor persons do not necessarily constitute a "suspect class" for purposes of constitutional analysis. See Harris v. McRae, 448 U.S. 297, 323 (1980) ("[P]overty, standing alone, is not a suspect classification.") However, "if a law impinges upon a fundamental right explicitly or implicitly secured by the Consitution, [it] is presumptively unconstitutional." Id. at 312 (quoting Mobile v. Bolden, 446 U.S. 55, 76 (1980) (plurality opinion)) (brackets in original). Because privacy is a fundamental constitutional right, see note 5 supra, a practice that discriminates against the privacy interests of the poor cannot be sustained without compelling justification.

103. The clearest guidance as to how to identify reasonable expectations of privacy ever offered by a majority of the Supreme Court appeared in Rakas v. Illinois, 439 U.S. 128, 143-44 n.12 (1978) (courts should refer "to concepts of real or personal property law or to understandings that are recognized and permitted by society"). Concurring in Rakas, Justice Powell noted that the majority's suggestion would "not provide law enforcement officials with a bright line" and would lack "ready administration." Id. at 152. Justice Powell then admirably attempted to provide some guiding principles for application of the reasonable expectation of privacy theory. He identified four general categories that courts should examine when appliying the analysis: (1) the precautions taken to maintain privacy; (2) the manner in which a location or object is used; (3) whether the type of governmental intrusion at issue was thought objectionable at the time the Fourth Amendment was enacted; and (4) any applicable property or possessory interests. Id. at 152-53. Unfortunately, Justice Powell did not specify how these factors were to be weighed in the privacy analysis; although he recognized that his categories would not provide much more specific guidance, he argued that "facile solutions" were unavailable. Id. at 156. No subsequent Supreme Court decision has adopted Justice Powell's suggestions, and they remain the Court's only true attempt at clarification of current Fourth Amendment privacy analysis.

104. See, e.g., United States v. Ocampo, 650 F.2d 421 (2d Cir. 1981) (unzipped fight bags); United States v. Markland, 635 F.2d 174 (2d Cir. 1980), cert. denied, 451 U.S. 991 (1981) (zippered plastic beverage bag); United States v. Mackey, 626 F.2d 684 (9th Cir. 1980) (paper bag) United States v. Neumann, 585 F.2d 355 (8th Cir. 1978) ("unsecured cardboard box"); State v. Schrier, 283 N.W.2d 338 (lowa 1979) (knapsack).

105. See, e.g., United States v. Cleary, 656 F.2d 1302 (9th Cir. 1981), petition for cert. filed, 50 U.S.L.W. 3502 (Dec. 22, 1981) (unzipped canvas bag); United States v. Ross, 655 F.2d 1159 (D.C. Cir.) (en banc), cert. granted, 50 U.S.L.W. 3265 (Oct. 13, 1981) (paper bag); United States v. Rigales, 630 F.2d 364 (5th Cir. 1980) (zippered leather case); United States v. Dien, 609 F.2d 1038 (2d cir. 1979), alT'd on rehearing, 615 F.2d 10 (1980) (taped cardboard boxes); United States v. Bloomfield, 594 F.2d 1200 (8th Cir. 1979) (knapsack).

106. See Dworkin, supra note 71 , at 334 (current analysis, "which assumes that fourth amendment law can develop meaningfully on a case by case basis, . . . is an abysmal failure"); LaFave, 
Such judicial confusion creates even greater difficulties for law enforcement officials, whose conduct is theoretically guided by judicial interpretation of the Fourth Amendment. ${ }^{107}$ When confronted with a multitude of potential privacy claims, the officer on the street using the lesser interests approach has little to rely upon besides his own estimation of their importance, which may well differ from that of the suspect, another officer, or later, a judge. ${ }^{108}$ Errors will inevitably be made, and a system of law enforcement based on such indefinite and shifting ground is undesirable for citizens as well as unworkable for the police. ${ }^{109}$

\section{Warrant Costs and the Constitutional Bargain}

Even if a fair and workable hierarchy of privacy interests were possible, Fourth Amendment protections for lesser interests should not be reduced to save the cost of a warrant. The public interest in efficient law enforcement is emminently valid. But putting aside the possibility that foregoing the warrant requirement may not be truly cost-effective, ${ }^{110}$ the claim of police efficiency must be analyzed in light of our constitutional history.

"Case-By-Case Adjudication" Versus "Standardized Procedures": The Robinson Dilemma, 1974 SuP. CT. REV. 127, 141-43 (criticizing case-by-case decisionmaking in Fourth Amendment context).

107. See New York v. Belton, 101 S. Gt. 2860, 2863 (1981) (Fourth Amendment doctrine should guide police conduct in "day-to-day activities") (quoting LaFave, supra note 106, at 141); Amsterdam, supra note 21, at 369 (same); Dworkin, supra note 106, at 365 (same).

108. Cr. Robbins v. California, 101 S. Ct. 2841,2846 (1981) (plurality opinion) (as "disparate [case] results . . . indicate, no court, no constable, no citizen, can sensibly be asked to distinguish the relative "privacy interests' in" various containers). Law enforcement officers freely admit the confusion that they feel under current Fourth Amendment analysis. See Conboy, Letter to the Editor, N.Y. TIMES, October 6, 1981, at A30, col. 3 (letter from New York City Deputy Police Commissioner) (current Fourth Amendment rules "cannot be understood" by police due to their "obscurity"); $c f$. Robbins v. California, 101 S. Ct. 2841, 2851 (1981) (Rehnquist, J., dissenting) (" "[L]aw enforcement officers and prosecutorial authorities must find quite intolerable the present state of [Fourth Amendment] uncertainty." ") (quoting Coolidge v. New Hampshire, 403 U.S. 443, 490 (1971) (Harlan, J., concurring)).

109. Besides providing no guidance for police, uncertain Fourth Amendment rules lead to increased suppression litigation and consequent exclusion of evidence. Lack of clarity also leaves citizens uncertain and uneasy regarding the extent of their protection under the Constitution. See New York v. Belton, $101 \mathrm{~S}$. Ct., 2860, 2864 (1981) (if rules are unclear "person cannot know the scope of his constitutional protection, nor can a policeman know the scope of his authority"); Dworkin, supra note 71, at 365 (if rules are unpredictable, "police are encouraged to perform questionable searches and seizures" which, in turn, "results in unnecessary invasions of individual rights and in litigation which could well have been avoided"); LaFave, supra note 106, at 142 (result of uncertain rules "may be the sustaining of motions to suppress" as well as uncertain security for privacy rights).

110. Cost effectiveness of the warrant process has never been empirically examined by courts or commentators, yet it is not an insubstantial issue. Searches conducted pursuant to a validly obtained warrant are more likely to be favorably viewed by courts, see Spinelli v. United States, 393 U.S. 417, 419 (1969) (magistrate's "determination of probable cause should be paid great deference by reviewing courts"); United States v. Ventresca, 380 U.S. 102, 106 (1965) (noting "preference to be accorded searches under a warrant"), and by juries, see Note, supra note 32, at 692 (warranted searches are "presumptively lawful" and create "favorable impression on both court and jury"). Therefore, probative evidence seized under warrant is less likely to be excluded by courts. In addition, resources of the criminal justice system viewed as a whole may well be conserved by an increase in warrant usage, because suppression litigation will become less time-consuming and may even be foregone in cases 
The Fourth Amendment represents a compromise between the interest in unfettered law enforcement and the interest in the privacy and security of one's "effects." 111 The Amendment with its warrant requirement reflects the considered views of our constitutional forefathers as to how the balance should be struck. ${ }^{12}$ Weighing anew the cost of a warrant against its benefits each time a privacy interest is at stake reopens a decision that has already been made as part of the constitutional bargain, ${ }^{113}$ and thereby constitutes a "double-counting" of the law enforcement factor. So long as the warrant requirement stands as a central component of Fourth Amendment jurisprudence, its protections must be deemed worth their cost, and the requirement should "operat[e] as a matter of course." 114 Because warrant costs thus assume a "zero weight" in modern Fourth Amendment analysis, ${ }^{115}$ even "lesser" privacy interests should tip the scales in favor of full Fourth Amendment protection. ${ }^{116}$

where a search cannot be challenged as warrantless. See Israel, supra note 32, at 252 \& n.127 (noting "legal and practical advantages that attach to the use of warrants"). Supreme Court Justices have disagreed about the magnitude of the burdens imposed by the warrant process without supportive citation. Compare Steagald v. United States, 101 S.Ct. 1642, 1652 (1981) (inconvenience for police is "simply not that significant") with id. at 1655 (Rehnquist, J., dissenting) (burden on police "is great"). It would be senseless to accept a new Fourth Amendment analysis that entailed a loss of warrant protection without becoming more certain of the costs involved.

111. See Dunaway v. New York, 442 U.S. 200, 208 (1979) ("long prevailing standards" of Fourth Amendment represent "best compromise that has been found for accommodating the often opposing interests in safeguarding citizens from rash and unreasonable interferences with privacy and in seeking to give fair leeway for enforcing the law') (quoting Brinegar v. United States, 338 U.S. 160,176 (1949)) (quotation marks and brackets omitted).

112. See Mincey v. Arizona, 437 U.S. 385, 393 (1978) ("[T]he Fourth Amendment reflects the view of those who wrote the Bill of Rights that the privacy of a person's home and property may not be totally sacrificed in the name of maximum simplicity in enforcement of the crimial law."); $c f$. Steagald v. United States, 451 U.S. 204, 222 (1981) ("Any warrant requirement impedes to some extent the vigor [of law enforcement], yet the Fourth Amendment recognizes that this restraint is necessary is some cases to protect against unreasonable searches and seizures."); Yackle, supra note 37 , at 386 ("[F]ramers could hardly have intended to closely circumscribe warranted police action, but to leave warrantless action largely unimpeded.")

113. Cf. Dunaway v. New York, 442 U.S. 200, 213-214 (1979) (Fourth Amendment's protections may not be reduced by "balancing of the miltifarious circumstances presented by different cases" because "the requisite "balancing' has been performed in centuries of precedent"); Coolidge v. New Hampshire, 403 U.S. 443, 481 (1971) ("warrant requirement has been a valued part of our constitutional law for decades" and is not to be reconsidered in each case).

114. Coolidge v. New Hampshire, 403 U.S. 443, 481 (1971).

115. Cf. Mincey v. Arizona, 437 U.S. 385, 393 (1978) ("[T]he mere fact that law enforcement may be made more efficient can never by itself justify disregard of the Fourth Amendment. The investigation of crime would always be simplified if warrants were unnecessary.") (citation omitted); Marshall v. Barlow's, Inc., 436 U.S. 307, 322 (1978) (rejecting argument that "administrative burdens" caused by warrant process outweigh "incremental protections afforded . . . privacy" by that process); Coolidge v. New Hampshire, 403 U.S. 443, 481 (1971) (warrant requirement "is not an inconvenience to be somehow 'weighed' against the claims of police efficiency"); Johnson v. United States, 333 U.S. 10, 15 (1948) ("II]nconvenience to the officers and some slight delay necessary to prepare papers and present the evidence to a magistrate . . . certainly are not enough to by-pass the constitutional [warrant] requirement.")

116. Thus the spirit of William Pitt's eloquent claim for protection of the least secure residence can be realized in the privacy context. See Miller v. United States, 357 U.S. 301, 307 (quoting Pitt from 1763) ("The poorest man may in his cottage bid defiance to all the forces of the Crown. It may 
Privacy

\section{A New Framework for Analysis}

Three goals of Fourth Amendment privacy analysis emerge from the discussion above: accomodation of a broad diversity of privacy claims, and nondiscriminatory and workable analytical results. In light of the failure of current Fourth Amendment analysis to achieve these goals, a new analytical framework is necessary. Using a definition of privacy such as secrecy and solitude, courts should err on the side of Fourth Amendment protection, ${ }^{117}$ and should develop inclusive "bright-line" standards to consistently guide law enforcers. Application of this new approach demonstrates that a "closed, opaque container" rule for warrant application in container search cases is appropriate, and that certain case results should be reappraised.

\section{A. Fourth Amendment Analysis}

The promise of Katz-expansive protection of privacy under the Fourth Amendment-has not been fulfilled under current privacy analysis. ${ }^{118}$ As a fundamental right, privacy requires strict and broad protection.

Because the importance of privacy interests cannot be fairly or accurately ranked on a relative scale, the scope of the Fourth Amendment should encompass even those interests that seem insubstantial to many members of society. ${ }^{119}$ A showing of some compelling societal need may justify reduction in Fourth Amendment protection for such interests on some occasions, ${ }^{120}$ but the cost of administering the warrant process, without more, should never be held to counterbalance a recognized privacy

be frail; its roof may shake; the wind may blow through it; . . . but the King of England cannot enter ... the ruined tenement!")

117. Cf. Gavison, supra note 5, at $467-71$ (law should make "explicil commitment to privacy" as a "central value").

118. The Supreme Court has applied the reasonable expectation of privacy test to deny Fourth Amendment protection to claims that clearly appear to invoke some cognizable privacy interest. Sec, e.g., Smith v. Maryland, 442 U.S. 735, 744 (1979) (upholding warranless use of pen registers to record local numbers dialed on telephone); South Dakota v. Oppermann, 428 U.S. 364, 367-69 (1976) (upholding warrantless police inventory search of closed automobile glove compartment); United States v. Miller, 425 U.S. 435, 442 (1976) (upholding warrantless seizure and examination of bank records created under Bank Secrecy Act of 1970). Cf. Amsterdam, supra note 21, at 385 (reasonable expectation of privacy analysis "fails to capture" spirit of Katz); Yackle, supra note 37, at 362 ("Burger Court has used the Katz approach . . . to restrict rather than to expand the scope of constitutional protection."); see also notes 21 \& 71 supra (citing critics of reasonable expectation of privacy analysis).

119. See pp. 331-33 supra (criticizing hicrarchical approach to privacy); cf. Cohen v. California, 403 U.S. 15, 24-25 (1971) (freedom of expression must be broadly construed, to effect "constitutional policies" of "individual dignity and choice upon which our political system rests"); L. TRIBE, AMIERICAN CONSTITUTIONAL LAW $\$ 12-1$, at 579 (1978) (any theory of freedom of speech should "protect a rich variety of expressional modes").

120. See pp. 317, 321-22 (exceptions to Fourth Amendment requirements granted upon showing of "compelling societal need"). 
interest. ${ }^{121}$ Moreover, once a privacy interest has been implicated, the burden of persuasion to justify intrusions should remain on parties opposed to full Fourth Amendment protection, ${ }^{122}$ and exceptions, if granted, should be narrowly circumscribed in order to provide maximum protection for the interests at stake. In short, all privacy interests should be analyzed equally under the Fourth Amendment, to prevent subtle or unwitting discrimination against minority-held privacy interests.

Under the suggested approach, Fourth Amendment analysis would still proceed in two steps. First, determination of the scope of constitutional protection would focus on identification of secrecy or solitude. Second, protective application would focus on the presence of exigency or other compelling societal interest that might justify reducing Fourth Amendment protections. Any identified privacy interests would be accorded the full protection of the Amendment, including the warrant requirement, unless some counterbalancing justification other than the expense of the warrant itself were demonstrated.

Courts should develop and apply the proposed analysis in a manner that provides comprehensible guidance to police. ${ }^{123}$ Because privacy is not concrete as is property, and is therefore more difficult to identify in the field, courts should use the suggested analysis to develop "bright-line" standards that can be easily applied by law enforcers. ${ }^{124}$ This is not to suggest, however, that any bright line is acceptable. On the contrary, such standards should be consistent with the broad, nondiscriminatory foundation of the proposed analytical framework, and therefore be drawn at the outer bounds of any particular area of application. ${ }^{125}$ Such standards will

121. See pp. 335-36 supra (warrant costs already included in "constitutional bargain" of the Fourth Amendment); $c f$. Stanley Illinois, 405 U.S. 645, 656 (1972) ("Constitution recognizes higher values than speed and efficiency" and Bill of Rights was designed to protect rights from "overbearing concern for efficiency"); Reed v. Reed, 404 U.S. 71, 76 (1971) ("objective of reducing the workload on probate courts . . . is not without some legitimacy," but it does not justify sex discrimination under equal protection clause).

122. See p. 325 \& note 67 supra (criticizing implicit burden of proof shift emerging in Fourth Amendment analysis).

123. See note 107 supra (one goal of Fourth Amendment analysis is to guide conduct of law enforcement officers).

124. See New York v. Belton, 101 S. C1. 2860,2863 (1981) (praising Fourth Amendment rules that are "straightforward, . . . easily applied, and predictably enforced," because they enable police to "reach a correct determination beforehand as to whether an invasion of privacy is justified in the interest of law enforcement" ") (quoting LaFave, supra note 106, at 142); Dunaway v. New York, 442 U.S. 200, 213-14 (1979) ("single, familiar standard is essential" for police officers, "who have only limited time and expertise").

125. See, e.g., United States v. Cleary, 656 F.2d 1302, 1304-05 (9th Cir. 1981), petition for cert. filed, 50 U.S.L.W. 3502 (Dec. 22, 1981) (drawing inclusive bright-line rule for container searches, based on "desirability of drawing clear lines in fourth amendment adjudication" and "dramatic [unprotective] consequences of an alternative approach"); United States v. Ross, 655 F.2d 1159, 1170 (D.C. Cir.) (en banc), cert. granted, 102 S. Ct. 386 (1981) (same). 
protect privacy and yet provide police with a Fourth Amendment analysis that is workable on a day-to-day basis.

\section{B. Container Searches}

Because the expectation of privacy and lesser interests approaches inevitably cause confusion, police searches of containers are currently a source of much Fourth Amendment conflict. ${ }^{126}$ Container searches therefore provide a useful backdrop for application of the privacy analysis proposed above. A "container" is anything that can enclose another object; it might be an automobile trunk, a suitcase, or a paper bag. ${ }^{127}$ Police typically seize such containers in the course of an arrest, upon suspicion that they contain contraband or criminal evidence. ${ }^{128}$ Because such containers, once lawfully seized, are in the "exclusive control" of the police, delaying a search of the containers to seek a warrant presents no risk of loss or destruction of the contents. ${ }^{129}$ How should the non-exigent search of such containers be dealt with under the Fourth Amendment?

A container that successfully prevents outside identification of its contents preserves privacy in the sense of secrecy, and therefore should fall

126. See p. 334 supra (listing conflicting results in container-search cases). Judge Tamm has compiled an exhaustive list of container-search decisions. See United States v. Ross, 655 F.2d 1159, 1174-75 nn.3 \& 4 (D.C. Cir.) (Tamm, J., dissenting), cert. granted, 102 S. Ct. 386 (1981).

127. Cf. New York v. Belton, 101 S. Ct. 2860, 2864 n.4 (1981) ("Container' here denotes any object capable of holding another object.")

128. See, e.g., Robbins v. California, 101 S. Ct. 2841, 2844 (1981) (packages seized and searched after defendant was arrested and placed in patrol car); Arkansas v. Sanders, 442 U.S. 753, 755 (1979) (suitcase seized and searched after arrest of taxicab passenger); United States v. Chadwick, 433 U.S. 1, 4 (1977) (footlocker seized and searched 90 minutes after arrest of owners). In virtually all such cases, if officers have probable cause to believe that the container contains contraband, they also have probable cause to arrest its possessor. See 2 RINGEL, SEARCHES \& SEIZURES, ARRESTS AND CONFESSIONS $\S 23.3$ (a), at 23-9 through 23-15 (2d ed. 1980) (probable cause for arrest in contraband cases is established not only by sight of contraband, but also by smell, sight of common contraband containers, suspicious behavior, informants" tips, and other "special rules"). Thus it is difficult to imagine a situation in which the person holding a container that may be validly seized and searched could not also be detained validly until a warrant for the container search was obtained. But see United States v. Ross, 655 F.2d. 1159, 1200 (D.C. Cir. 1981) (Wilkey, J., dissenting), cert. granted, 102 S. Ct. 386 (1981) (when automobile is stopped on probable cause that it contains contraband, it is "normally the case" that owners cannot be detained).

Judge Wilkey has argued that because such situations might arise, a warrant should not be required, because if the warrant is refused for lack of probable cause, the arresting officer might be open to a "constitutional tort action" for unlawfully detaining the container's owner. Id. at 1199 . Putting aside the issue of whether such a distant possibility, see note 40 supra (damages actions against police unlikely to succeed), should justify a sacrifice of Fourth Amendment privacy protection, Judge Wilkey's criticism proves too much. For if an officer were not required to obtain a warrant in such circumstances and instead searched the container on the spot, he would still be open to a hypothetical "constitutional tort action" on grounds of "unlawful search," if he had no probable cause for his action. Foregoing the warrant requirement for containers, then, will still fail to protect officers from the litigious, innocent victims of their excesses.

129. United States v. Chadwick, 433 U.S. 1, 13 (1977); accord Arkansas v. Sanders, 442 U.S. 753, 762 (1979). 
within the scope of the Fourth Amendment ${ }^{130}$ and generally be protected by the warrant requirement. On the other hand, open or transparent containers that reveal their contents to plain view, or permeable containers that permit positive identification of their contents by releasing distinctive odors or other perceptual cues unmistakable to the human senses, do not embody privacy interests, and police should be allowed to examine them upon probable cause alone. ${ }^{131}$

Containers that are flimsy or not commonly thought of as carriers for personal effects should also receive full protection under the Fourth Amendment if they preserve secrecy. ${ }^{132}$ The distinction between tenuous

130. Despite the lack of a clear privacy definition or analysis, most courts have held that closed, opaque containers fall with the scope of the Fourth Amendment, and have required at least probable cause for their search. Cf. p. 326 supra (Supreme Court requires probable cause for warrantless automobile searches).

131. See Robbins v. California, 101 S. Ct. 2841, 2846 (1981) (plurality opinion) (Fourth Amendment does not protect containers that are "transparent" or "open to "plain view' "); Arkansas v. Sanders, 442 U.S. 753, 764-65 n.13 (same). The Supreme Court has never approved a "plain sense" equivalent to the "plain view" exception, cf. Johnson v. United States, 333 U.S. 10, 13 (1948) ("odors alone do not authorize a search without warrant"), but lower courts have approved such a concept if the sensation is unmistakable and obvious to the "unaided" senses. See, e.g., United States v. Russell, 655 F.2d 1261, 1264 (D.C. Cir. 1981), rev'd on reh'g on other grounds, No. 1139 (D.C. Cir. Jan. 22, 1982) (when officer felt gun in lawfully seized paper bag, "[u]ncovering what his sense of touch revealed did not require a warrant"); United States v. Ocampo, 650 F.2d 421, 429 (9th Cir. 1981) (endorsing " 'plain feel' version of the 'plain view' doctrine"); United States v. Solis, 536 F.2d 880, 881 (9th Cir. 1976) ("[E]vidence acquired by unaided senses . . . is usable under doctrines of plain view . . .."); United States v. Bronstein, 521 F.2d. 459, 461 (2d Cir. 1975), cert. denied, 424 U.S. 918 (1976) (if police officers detected odors "through their own olfactory senses, there could be no serious contention that their sniffing . . . would be tantamount to an unlawful search").

Unaided perception of the identity of a container's contents, if as certain as visual ascertainment, would preclude any claim to secrecy. Thus such "plain sense" exceptions would be valid within the analytical framework proposed here.

132. Cf. Robbins v. California, 101 S. Ct. 2841, 2846 (1981) (plurality opinion) (any "closed, opaque container" is protected by the warrant requirement); accord, United States v. Weber, 664 F.2d 841 (1st Cir. 1981) (refusing exception to warrant requirement for rolled-up rainslicker, and adopting Robbins" "closed, opaque container" rule); United States v. Ross, 655 F.2d 1159, 1170-71 (D.C. Cir.) (en banc), cert. granted, 102 S. Gt 386 (1981) (refusing exception to warrant requirement for "unworthy" containers); United States v. Moschetto, 646 F.2d 955, 961 (5th Cir. 1981) (refusing "to create a blanket exception to the Fourth Amendment for paper bags . . . based upon durability of common usage"; $c f$. United States v. Cleary, 656 F.2d 1302 (9th Cir. 1981), petition for cert. filed, 50 U.S.L.W. 3502 (Dec. 22, 1981) (refusing exception to warrant requirement for unzipped canvas bag).

In his unreported panel decision in Ross, supra, Judge Tamm was apparently the first to explicitly apply a hierarchical privacy analysis to containers, holding that the warrant requirement did not apply to paper bags because they "can fall open or break very easily" and àre not "a normal place" to store personal effects. Ross v. United States, No. 79-1624, slip op. at 14 (D.C. Cir. April 17, 1980), rev'd en banc, 655 F.2d 1159, cert. granted, 102 S. Ct. 386 (1981). Justice Powell has apparently adopted a similar hierarchical approach to container search cases. See Robbins v. California, $101 \mathrm{~S}$. Ct. 2841, 2850 n.3 (1981) (Powell, J., concurring). Five Circuit Courts of Appeal have applied expectation of privacy analysis to hold that warrants are not required for the search of closed paper bags because they are flimsy and unusual containers for personal effects. See United States v. Martino, 664 F.2d 860 (2d Cir. 1981); United States v. Mefford, 658 F.2d 588 (8th Cir. 1981); Virgin Islands v. Rassool, 657 F.2d 582 (3d Cir. 1981); United States v. Brown, 635 F.2d 1207 (6th Cir. 1980); United States v. Mackey, 626 F.2d 684 (9th Cir. 1980); see also United States v. Goshorn, 628 F.2d 697 (1st Cir. 1980) (questioned in Weber, supra); United States v. Jiminez, 626 F.2d 39 (7th Cir. 1980), vacated and remanded, 101 S. C. 3152 (1981). Brown and Mackey were decided before Robbins, and both opinions relied on the subsequently reversed panel decision in Ross. 
or unusual privacy interests and the absence of any privacy interest must be clearly drawn: the latter receive no Fourth Amendment cognizance but the former should be firmly and fully protected. Likewise, containers such as gun or violin cases, that only suggest but do not reveal their contents, should be held to implicate Fourth Amendment privacy interests. The identity of the contents of such outwardly suggestive containers will remain uncertain unless further government action is taken, and this privacy should be protected by the Fourth Amendment to the same extent as it is in the case of other more nondescript containers. ${ }^{133}$ The Supreme Court's suggestion to the contrary appeared only as dictum in a footnote, ${ }^{134}$ and should properly be rejected. ${ }^{135}$ In sum, all containers that are closed and opaque and otherwise preserve privacy should be fully subject to Fourth Amendment privacy analysis.

A bright-line rule mandating full Forth Amendment protection for all closed, opaque containers in non-exigent circumstances provides ease of administration for police, as well as complete protection for privacy interests. First, there is no reason to believe that police department property rooms will be overburdened by a multitude of containers, because officers must now bring back the evidentiary contents of containers that they search in the field. ${ }^{136}$ Second, any resultant reduction in suppression litigation surrounding such searches will result in less time spent in such proceedings by officers, and less cost for the criminal justice system as a whole. Third and most importantly, a distinct and understandable rule will reduce officers' confusion on the job. ${ }^{137}$

133. Cf. Robbins v. California, $101 \mathrm{~S}$. Ct. 2841, 2846 (1981) (plurality opinion) (only container that "clearly reveal[s] its contents" may be searched without warrant) (emphasis supplied). Contra, People v. Green, 115 Cal. App. 3d 259, 261, 171 Cal. Rptr. 210, 212 (C. App. 1981) (gun case "by its very nature cannot support a reasonable expectation of privacy"). Certainty regarding identity is of paramount importance when the definition of privacy as secrecy is applied; gun and violin cases do not necessarily contain the objects that they suggest. $C$. Sharpe v. United States, 660 F.2d 967, 980 (4th Cir. 1981) (Russell, J., dissenting) ("[S]omeone might . . . easily place socks, underwear, and a toothbrush in a gun case.") If the hypothetical gun case were securely within the control of the police, it would present no immediate danger to them and a warrant should be sought. If the situation were otherwise, an exigent circumstances rationale, see p. 322 supra, would justify an immediate search.

134. See Arkansas v. Sanders, 442 U.S. 753, 764-65 n.13 (1979) (suggesting that "some containers (for example a kit of burglar tools or a gun case) by their very nature" do not implicate Fourth Amendment privacy interests "because their contents can be inferred from their outward appearance").

135. See United States v. Ross, 655 F.2d 1159, 1170 (D.C. Cir.) (en banc), cert. granted, 102 S. Ct. 386 (1981) (footnote 13 in Sanders, see note 134 supra, states no more than "plain view" exception to warrant requirement); United States v. Moschetta, 646 F.2d 955, 961 (5th Cir. 1981) (same).

136. Presumably, officers now seize and search only those containers for which they have probable cause. Most warrantless container searches in the field should therefore yield criminal or evidentiary items that must be taken back to the department and stored in any event. Under a strict warrant rule it should be the case that only in a few instances will police bring back unopened containers that do not contain criminal items; if such is not the case, then a strict warrant rule will act to discourage a practice of unthinking general searches of containers.

137. See United States v. Ross, 655 F.2d. 1159, 1170 (D.C. Cir.) (en banc), cert. granted, 102 S. 
Finally, the new privacy analysis suggests that the law governing searches of automobiles should be thoroughly revised. ${ }^{138}$ Once lawfully seized, automobiles should be considered as no different from other large containers. ${ }^{139}$ In contrast to the Supreme Court's unsupported assertions, sociological evidence demonstrates that Americans associate strong privacy concerns with their cars. ${ }^{140}$ In non-exigent circumstances, the warrant requirement should be strictly applied to all the areas of an automobile that preserve privacy, including the trunk, glove compartment, and hidden areas of the passenger compartment. ${ }^{141}$ In addition, the "inventory exception" that permits warrantless searches of impounded automobiles should be reexamined to the extent that it is based on the presumption that automobiles generally embody "lesser" interests in privacy. ${ }^{142}$ Protective,

Ct. 386 (1981) (rejecting exception to warrant requirement for "unworthy containers" because "most importantly, it would destroy the coherence of a well-established, clear, eminently manageable rule"); United States v. Moschetta, 646 F.2d 955, 962 (5th Cir. 1981) ("to allow some but not all containers to be protected ... would be to cause worse confusion" for police).

The standard endorsed here may be overinclusive, protecting containers in some cases when their owners actually have no interest in their privacy. To avoid the delay of seizure and warrant application, such owners are always free to consent to an immediate search. $C f$. Chambers v. Maroney, 399 U.S. 42, 64 (1970) (Harlan, J., dissenting) (automobile owners who wish to avoid temporary seizure of their cars may consent to search). The point of any expansive per se rule, however, is that the costs of inclusivity are judged to be outweighed by the benefits of avoiding or reducing errors and the savings of administrative costs required for case-by-case determinations. $C f$. United States v. Container Corp., 393 U.S. 333, 341 (1969) (Marshall, J., dissenting) (in antitrust context, "/p/er se rules ... are justified on the assumption that the gains from imposition . . will far outweigh the losses").

138. This suggestion is by.no means original. See notes $53 \& 57$ supra (listing critics of current automobile search doctrine).

139. Cf. Yackle, supra note 37, at 404 (automobiles are "highly mobile containers").

140. As Professor LaFave has noted, no less than luggage, the "trunk of a car is . . . intended as a repository" of personal effects. W. LAFAVE, 2 SEARCHES AND SEIZURES $\S 7.2$, at 540-41 (1978 and Supp. 1980). Accord, Note, supra note 57, at 841 ("Using the car as a protected container, under lock and key, is general in American society."); see Allen \& Schaeffer, Great Expectations: Privacy Rights in Automobiles, 34 U. MIAMI L. REV. 99, 142 (1979) (due to pervasive "role of the automobile in today's society," Americans have "expanded expectations of privacy" when in their cars); Yackle, supra note 37, at 411 (persons "often seek privacy on wheels"); Note, supra note 57 , at $840 \mathrm{n} .28,841$ ("[f]or modern $\Lambda$ merica, the automobile has come to be seen as an expected place of privacy" and is "often used for private activities").

141. Trial courts will have to make factual findings regarding searches beneath seats or in back seats or hatch areas, with regard to whether or not items seized were secret, that is, not in plain view or its equivalent.

142. See South Dakota v. Opperman, 428 U.S. 364, 367-69 (1976) (upholding warrantless searches of impounded motor vehicles according to regularized procedures based on caretaking functions of police, noncriminal context of inventories, and "diminished" expectations of privacy in automobiles). The particular search at issue in Opperman was that of a closed glove compartment, obviously one of the most private areas of an automobile. On remand, the South Dakota Supreme Court held this search violative of the state constitution and ruled that inventory searches in general must be limited to "articles which are in plain view." State v. Opperman, 247 N.W.2d. 673, 675 (S.D. 1976). Cf. Wagner v. Commonwealth, 581 S.W.2d. 352, 357 (Ky. 1979) (automobile inventory searches impermissible absent consent or "substantial necessities grounded upon public safety") (based on state constitution). Despite Opperman's broad language, the Eighth Circuit has subsequently refused to uphold the warrantless inventory search of the trunk of an impounded automobile. See United States v. Wilson, 636 F.2d 1161, 1164 (8th Cir. 1980) (noting "greater expectation of privacy in the locked trunk" of a car, and distinguishing Opperman because that decision did not involve a 
bright-line standards can be developed for automobiles without wholly excluding them from Fourth Amendment protection. ${ }^{143}$

\section{Conclusion}

Protection of privacy under the Fourth Amendment has been confused and inconsistent. The law must develop a more objective and sociologically accurate description of privacy if privacy interests are to be preserved to the satisfaction of both citizens and police. Fourth Amendment analysis should be revised to include a more objective definition of privacy as secrecy and solitude when determining the scope of the Amendment, and to exclude warrant costs when applying its protections. Courts should use this approach to develop inclusive, non-discriminatory guidelines for police, so that the Fourth Amendment can be applied effectively yet fairly in the privacy context.

trunk search).

143. The Supreme Court evidently has taken a contrary view in its decision in New York v. Belton, 101 S. Ct. 2860 (1981). Based on the need for a "workable rule" for automobile searches incident to arrest, the Court held that the warrantless search of a vehicle and any containers within it is permissible whenever the occupants have been lawfully arrested. Id. at 2864. This decision not only eliminates warrant protection for cars and containers in them whenever a lawful arrest is made, but also apparently relieves officers from having to demonstrate that they have probable cause to search at all. Because this bright line is unprotective of the privacy interests in automobiles and removes them completely from the Fourth Amendment's protective scope, it unavoidably conflicts with the analytical framework that this Note proposes. 